Sultan Qaboos University Journal of Arts \& Social Sciences
جامعة السلطان قابوس مجلة الآداب والعلوم الاجتماعية

الإعـــلانُ القضــائيُ الإلكترونيٌ بين التقنينِ والتقنيَة

دراسة في ضوء القانون الاتحادي رقم • ا لسنة ع ا • ا المعدل لقانون

الإجراءات المدنية لدولة الإمارات العربية المتحدة

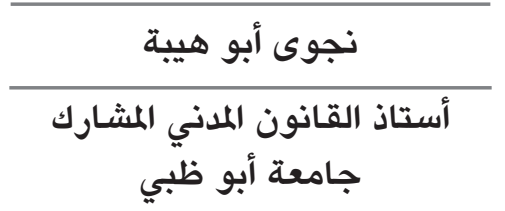

nagwa.abouhaiba@adu.ac.ae

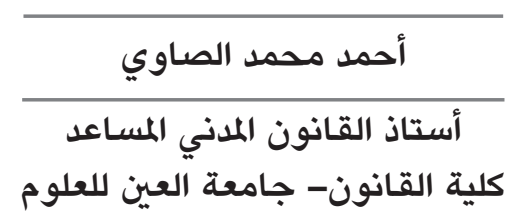

التكنولوجيا

Dr.a.sawi@gmail.com 


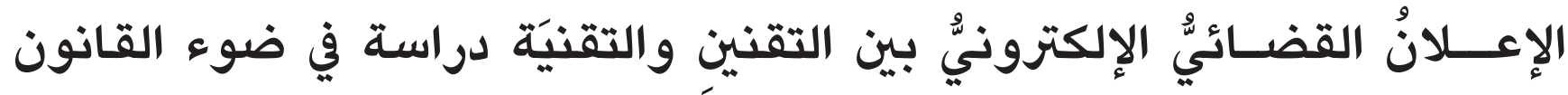

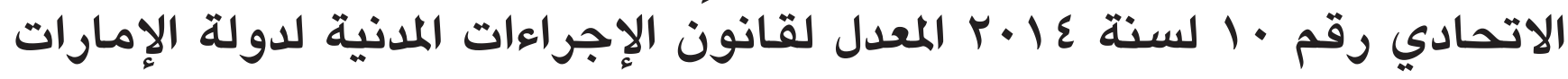 العربية المتحدة
}

أحمد محمد الصاوي ونجوى أبو هيبة

المنّّص:

يُعرف الإعلان القضائي أنه الوسيلة الرسمية لتمكين الطرف الآخر من العلم بإجراء معين، وهو الوسيلة التي يُبلغ بها خصم واقعة معينة

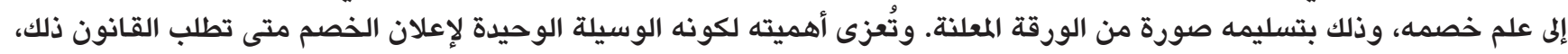

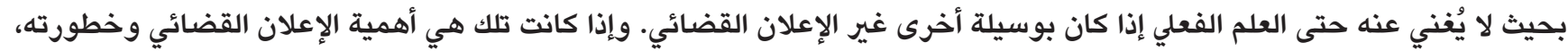

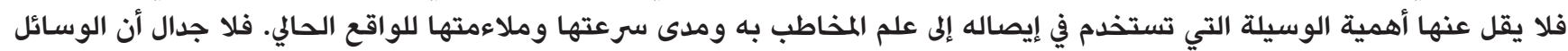
التقليدية التي يتم بها الإعلان أضحت وحدها قاصرة عن تلبية احتياجات العمل، سواء من ناحية تبسيط الإجراءات، أو من ناحية التهاية القصد

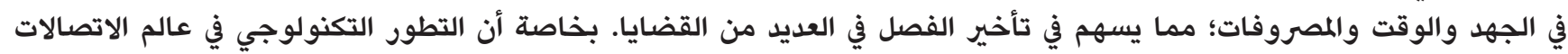

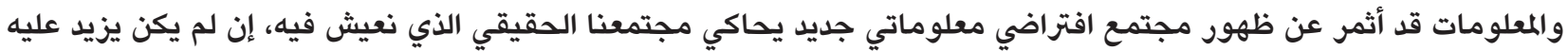

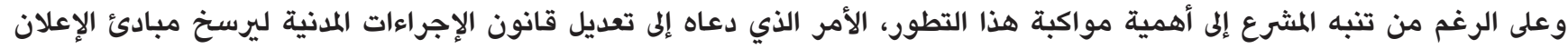

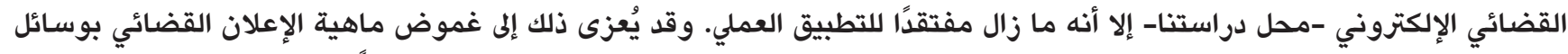

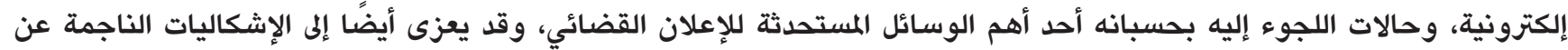

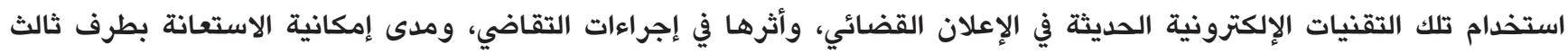

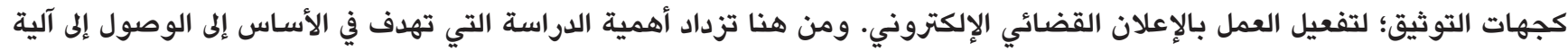

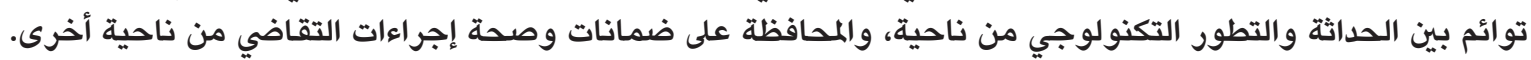

الكلمات المفتاحية: الإعلان القضائي- وسائل التقنية الحديثة- التوثيق الإلكتروني- قانون الإجراءات المدنية بدولة الإمارات العربية

المتحدة.

\section{The Electronic Judicial Notice: Between Legalization and Technology}

\author{
Ahmed M. Elsawi \& Nagwa Abouhaiba
}

\section{Abstract:}

The judicial notice is unquestionably important, and flawed execution undermines the procedural action and negates its legal effects. In this regard, the means used to deliver the judicial notice to the addressee, its speed, and its appropriateness for the context are as important as the notice itself. Traditional notification methods have become inefficient, both in terms of the simplification of procedures and in saving effort, time, and expenditure. This reveals the importance of this research: it aims primarily to activate the use of the electronic judicial notice and access to a mechanism that harmonizes modernity and technological development while maintaining the guarantees inherent in and the validity of the proceedings.

Keywords: judicial notice, technology, electronic authentication, UAE legal system. 
في الإعلان القضائي، وأثرها في إجراءات التقاضي. ومن هنا تزداد

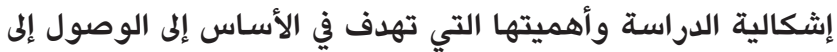

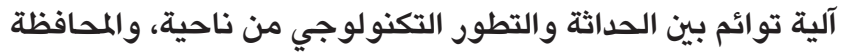

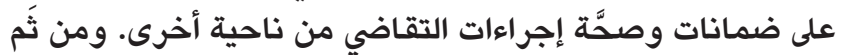
نحاول من خلال هذه الدراسة الإجابةً عن العديد من التساؤلات التات التات

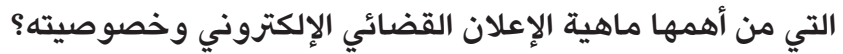

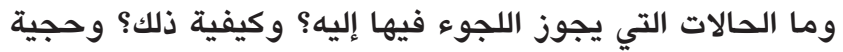

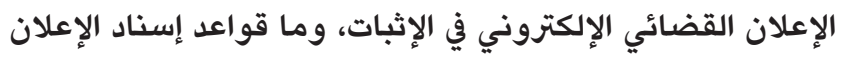

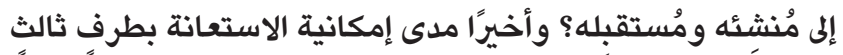
كجهات التوثيق لتفعيل العمل بالإعلان القضائي الإلكتروني.

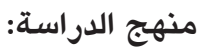
نتحو في دراستنا إلى منهج وصفي، تحليلي؛ لاعتمادنا على دراسة

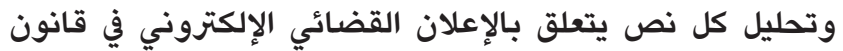

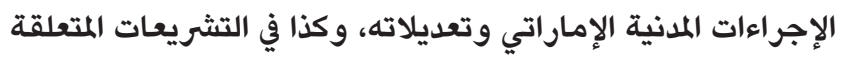
بالمعاملات الإلكترونية بحسبان خصوصية الوسيلة الإلكترونية

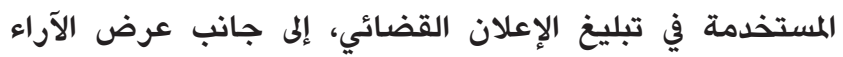

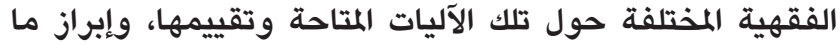
ينجم عنها من صعوبات وسُبل التغلب عليها. ولا يقتصر البحث على تناول موضوع الإعلان القضائي الإلكتروني في ظل فل نظام التام

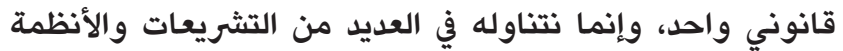
القانونية المختلفة متى اقتضت الحاجة لذلك.

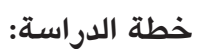
وترتيبًا على ما تقدَّم، نوزِّع الحديث على مطلبَيْن، نخصص الأول

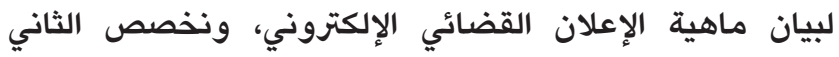

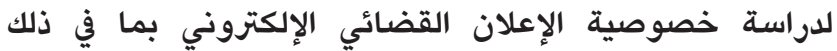
الإشكالياتُ المترتبة على استخدام الوسائل الإلكترونية.

المَلب الأول: ماهية الإعلان القضائي الإلكتروني

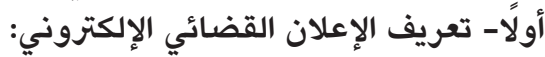

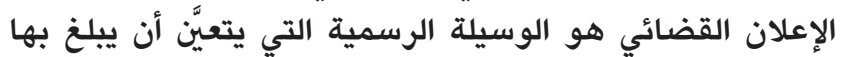

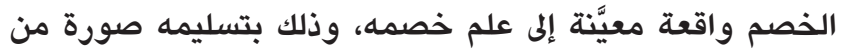

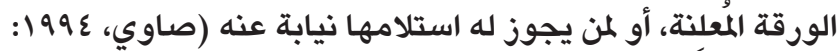
1EM). ويُقصد به أحد أمرين رئيسين: الأول يتمثل في إبلاغ المعلَن

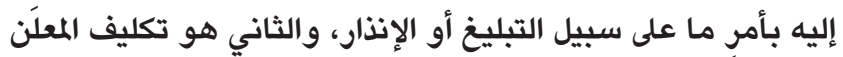

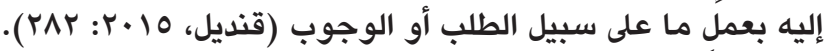

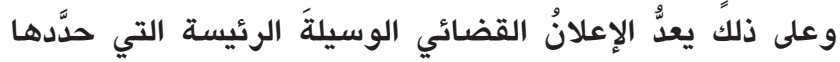
قانون الإجراءات المدنية لتمكين الطرف الآخر من العلم بإجراء القاءئ

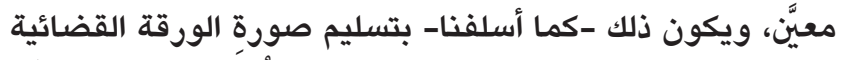
لهذا الإجراء -بواسطة القائم بالإعلان أو المُصرَّح لهـ لهـ إلى المعلَنَ

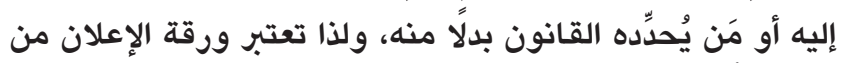

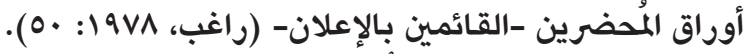

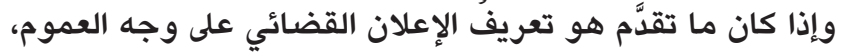
فلا يختلف عنه الإعلان القضائي الإلكتروني إلا باختلاف الوسيلة

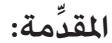

يُعرف الإعلان القضائي بأنه الوسيلة الرسمية لتمكين الطرف

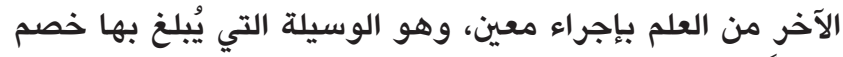

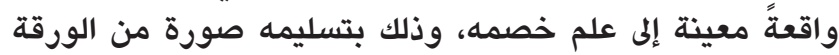
المعلنة. وتُعزى أهميته لكونه الوسيلة الوحيدة لإعلان الخصم

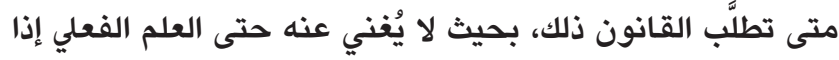

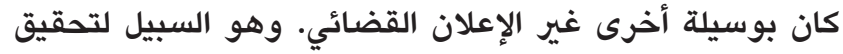

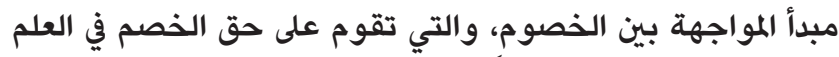

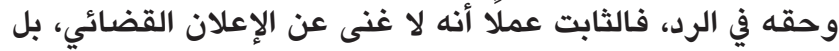

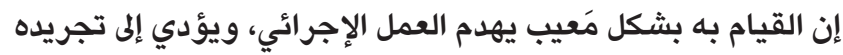

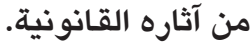

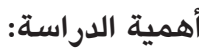
إذا كانت تلك هي أهمية الإعلان القضائي وخطورته، فلا تقلٌّ

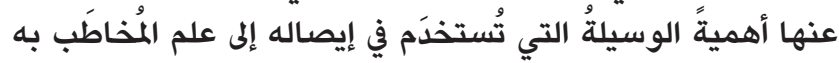
ومدى سرعتها وملاءمتها للواقع الحالي. فلا جدال أن الوسائل

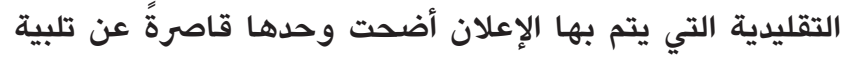
احتياجات العمل، سواء من ناحية تبسيط الإجراءات، أو القصد في في الجهد والوقت والمصروفات؛ مما يُسهم في تأخير الفصل في العديد

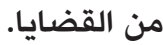

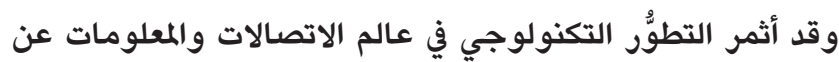

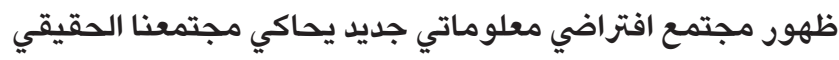
الذي نعيش فيه، إن لم يكن يزيد عليه. وهو ما حدا مدا بالعديد من

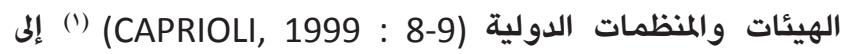

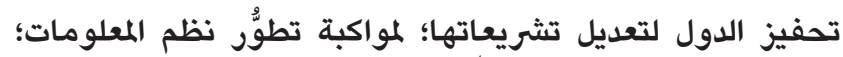

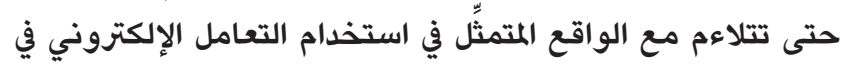
كافة المعاملات، وليس الإعلانات القضائية فحسب.

مشكلة الدراسـة: بالنظر إلى مكانة دولة الإمارات العربية المتحدة، والتي تُصنَّف

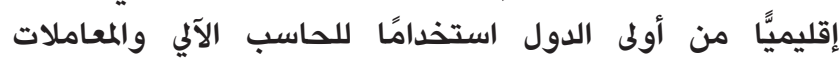

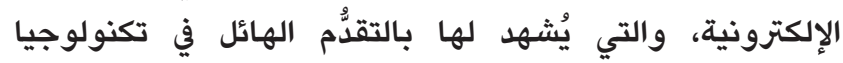

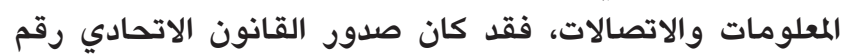

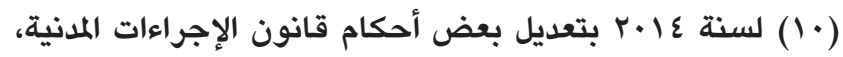

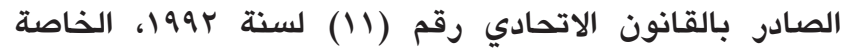
بالإعلان القضائي بوسائل التقنية الحديثة وليد الحاجة الحادة الماسَّة

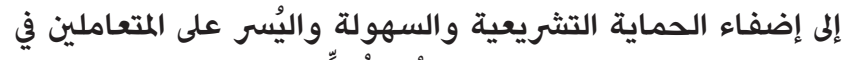

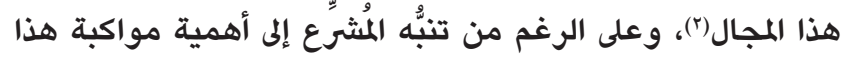

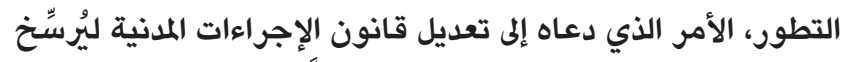

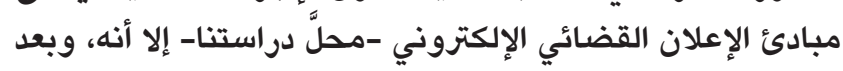

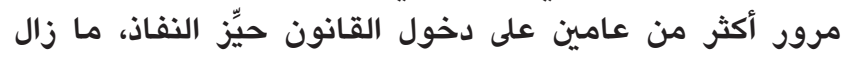

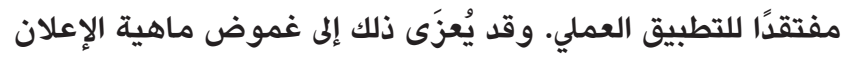

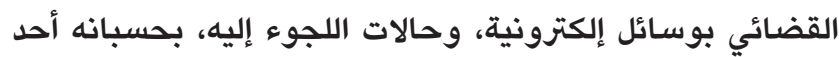

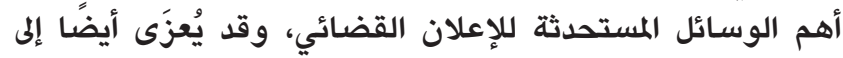
الإشكاليات الناجمة عن استخدام تلك التقنيات الإلكترونية الحديثة 
ومتى تم تسليم الإعلان بالطريق الذي رسمه القانون (سواء كان

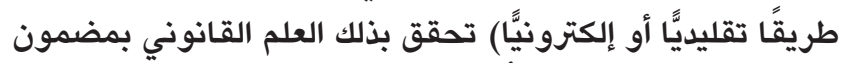

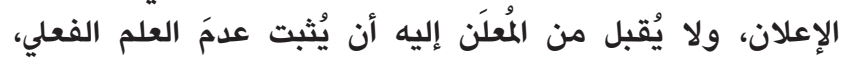

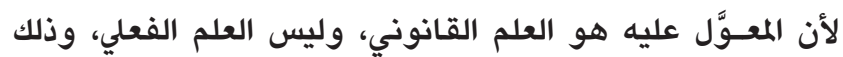
لافتراض العلم بالإعلان متى تم في الشكل الموليه القـانوني (الصاوي، 1991: 07)، وبالطريقة التي حددها القانون، سواء كاءني كان تقليديًّا

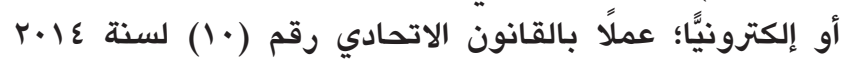

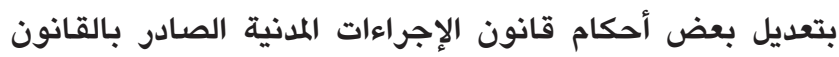

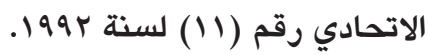

ثالثًا - صيغة الإعلان القضائي الإلكتروني:

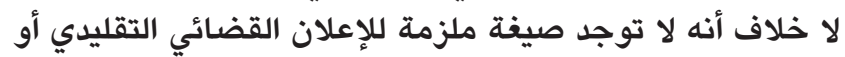

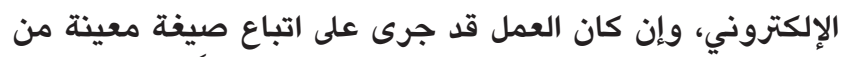

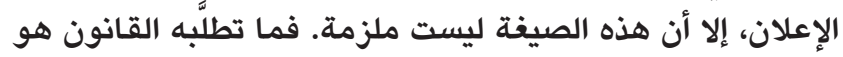

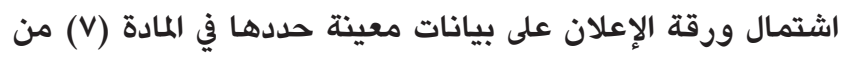

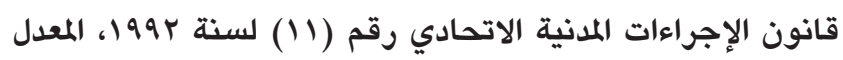

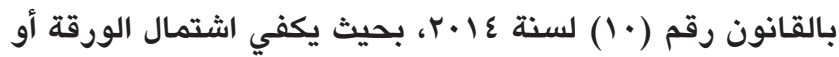

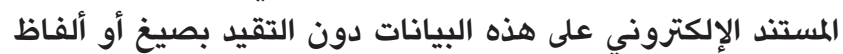

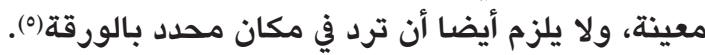

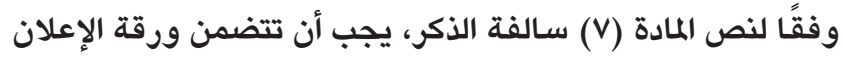
(التقليدي أو الإلكتروني) بيانات معينة، بدونها لا تأخذ الورقة الإنة

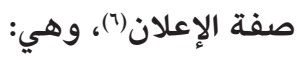

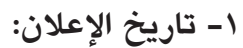

يجب على القائم بالإعلان أن يذكر تاريخ حصوله باليخ باليوم والشهر والسنة، بل والساعة التي حصل فيها الإعلان. ولتاريخ الإعلان

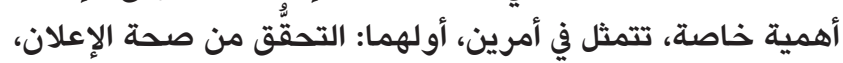
وما إذا كان قد صدر في الميعاد المسموح به. والأمر الثاني: تحديد إندا

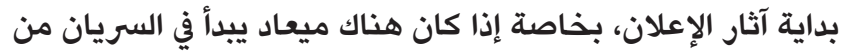
تاريخ الإعلان. ومثال ذلك سريان ميعاد الطعن من تاريخ إعلان

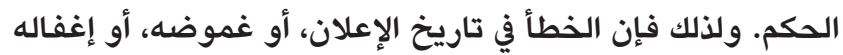

قد يؤدي إلى بطلان إجراء الإعلان.

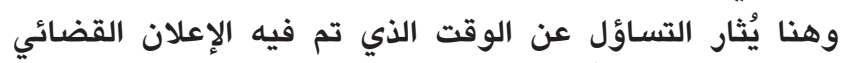

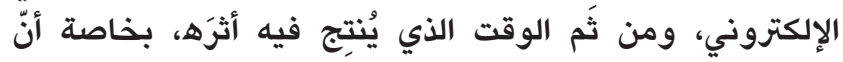

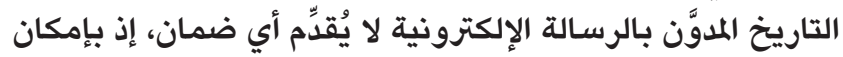

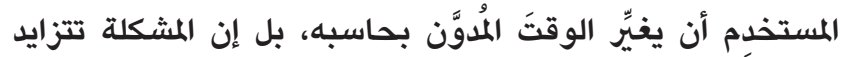
عند تعدد الأطراف المطلوب إعلانهم ووجودهم في أكثر من مكان في التوقيت نفسه، لأن مختلَف الحواسيب التي ستقوم بالاتصال ستعطي أزمنة مختلفة.

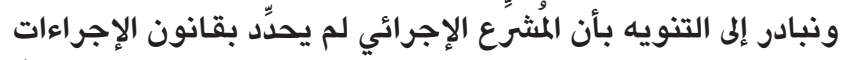

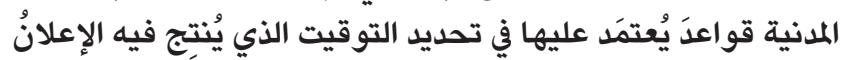

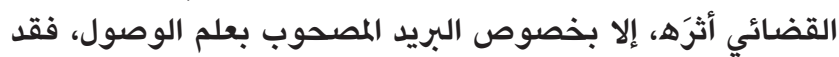
نصت المادة (• (1) في فقرتها الثالثة من قانون الإجراءات الات المدانية

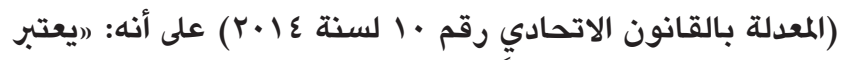

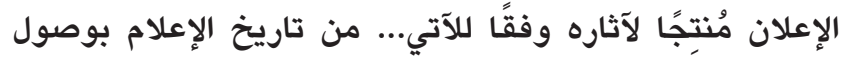

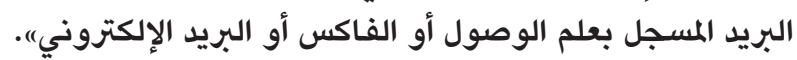

المستخدَمة في الإعلان ذاته، أي أن يكون الإعلان بطريقة إلكترونية،

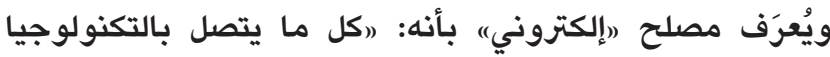
الحديثة ويكون ذا قدراتٍ كهربائية أو رقمية أو مغناطيسية أو مأولية

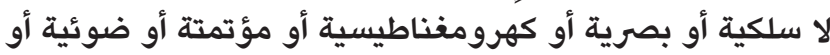
ما شابه ذلك)("). وعلى ذلك يمكن تعريف الإعلان القضائي الإلكتروني بأنه الوسيلة

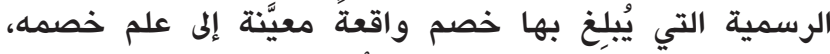

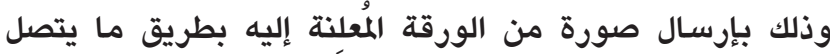

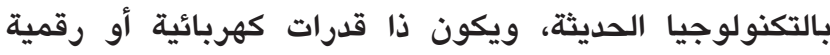
أو مغناطيسية أو لا سلكية أو بصرية أو كهرومغناطيسية أو

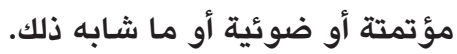

ثانيًا- أهمية الإعلان القضائي الإلكتروني:

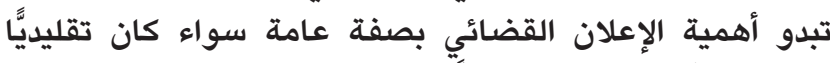

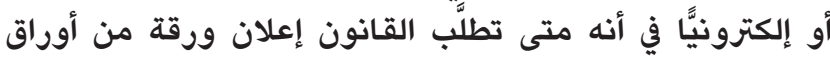
الإجراءات المدنية والمرافعات بوسيلةٍ ما، فإنها تعتبر الوبلة الوسيلة

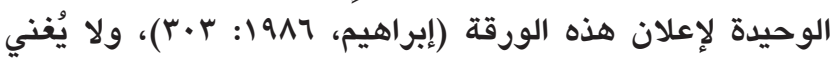

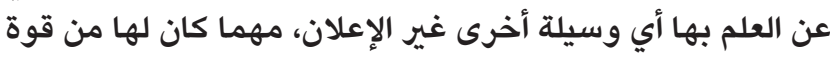

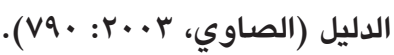
ولا تخفَى أهمية الإعلان القضائي في تحقيق مبدأ المواجهة بين الخصوم، والذي يقوم على حق الخصم في العلم التام في الوقت الإن

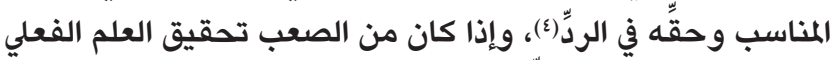

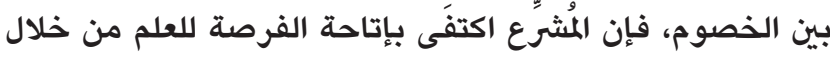

الوسائل التي يحددها، والتي منها وسائل التقنية الحديثة.

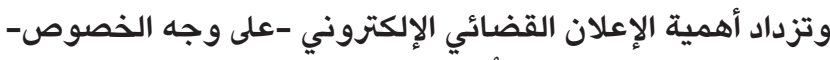

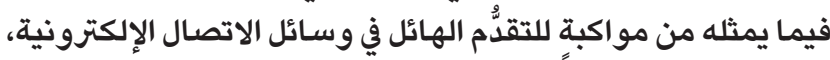
والتطور المستمر الذي لحق بها مع مع إنشاء شبكة المعلومات

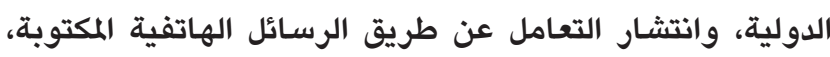

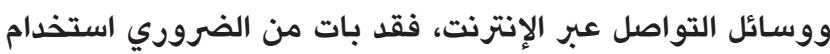

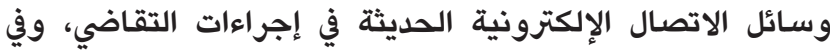

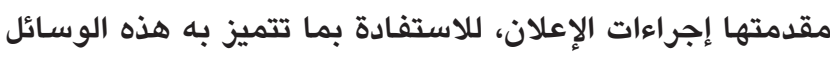

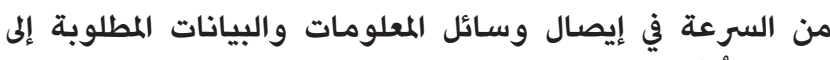

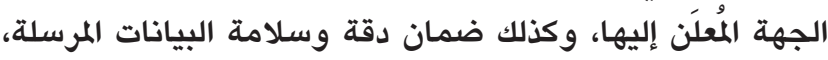

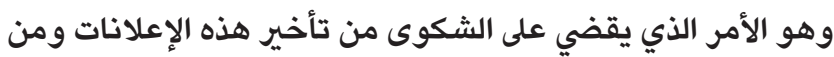
الأخطاء البشرية التي قد تصاحب تنفيذها.

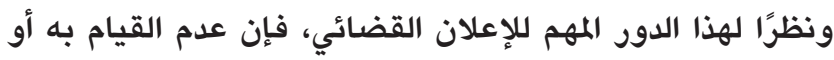

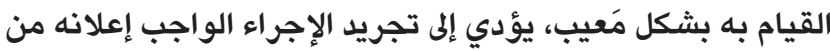

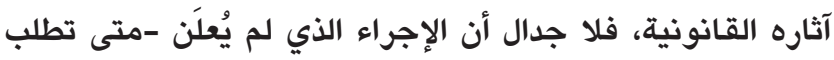
القانون ذلك- يعتبر منعدمًا في مواجهة من كان يجب إنباء إعلانه به

(MOREL, 1949:314)

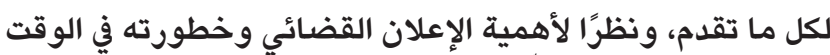

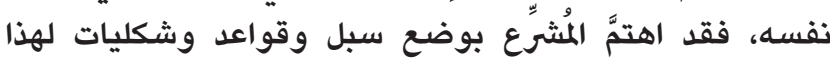
الإعلان، هدفها الأساس وصول مضمون ورقة الإعلان إلى علم

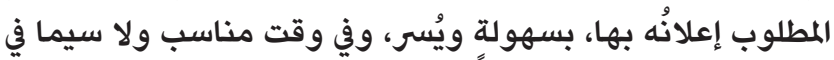

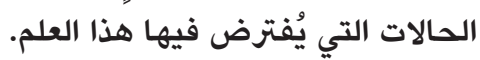


7-البيان الخاص بالقائم بالإعلان: يجب أن تشتمل ورقة الإعلان على اسم القائم بالإعلان، ووظيفته،

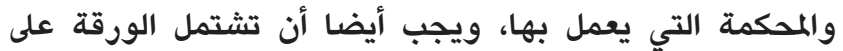
توقيعه. ونرى أنه لا مانع من أن يكون التوقيع إلكترونيًّ في حالة التاني الإعلان القضـائي الإلكتروني.

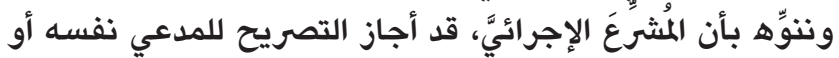

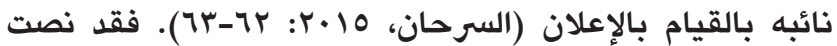
الفقرة الثانية من المادة الخامسة من قانون الإجراءات المات المدنية المعدلة على أنه: "اللمحكمة أن تُصرّح للمدعي أو وكيله للقيام

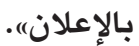
ويُثار التساؤل عن مدى جوالِّاز امتناع القائم بالإعلان القضائي

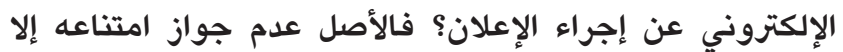
لمسوغ قوي كأن يمتنع حرصًا منه على النظام العام والآداب مثلاً كما لو تبين له اشتمال ورقة الإعلان على بيانات مخالفة للنظام

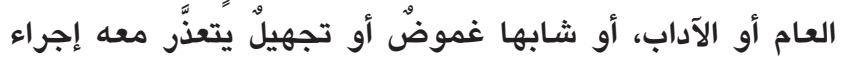

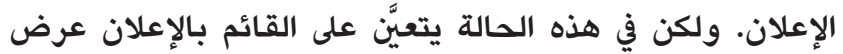
الأمر فورًا على مكتب إدارة الدعوى أو القاضي المختص، أون أو رئيس

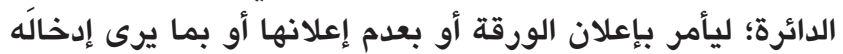

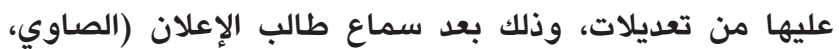

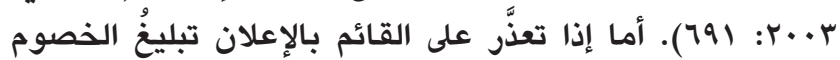

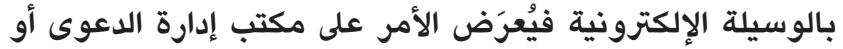

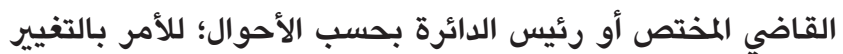

المناسب في طريقة الإعلان(').

المطلب الثاني: خصوصية الإعلان القضائي الإلكتروني تكمُن خصوصية الإعلان القضائي الإلكتروني في خصوصية الإنية الوسائل المستخدَمة في الإعلان ذاته، والتي تكون بين الإني غائبَيْنِ بوسائل تقنية تجهل مفهوم الحدود المكانية، بل والإقليمية،

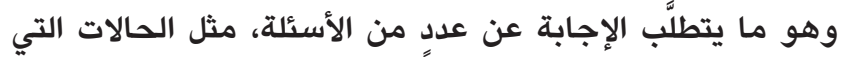
يُمكن اللجوء فيها إلى الإعلان القضائي الإلكتروني وكيفية ذلك؟ فئ الإني

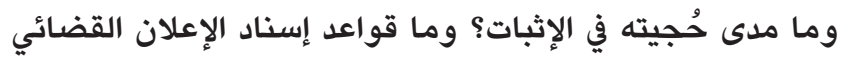

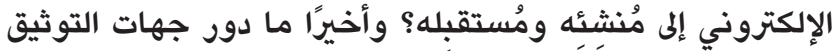

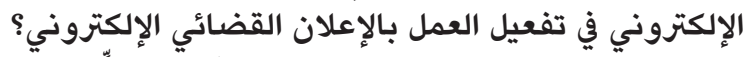

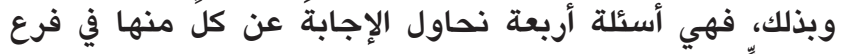
مستقلٍ على التفصيل فيل التالي:

الفرع الأول- حالات وكيفية الإعلان القضائي الإلكتروني:

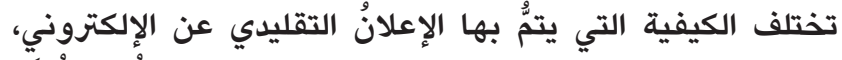

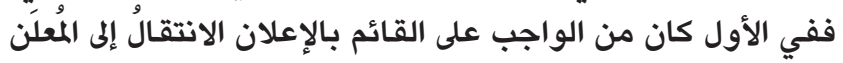

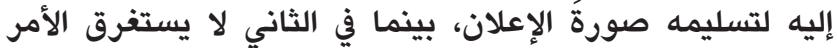

سوى ضغطة زر. وبمطالعة النصوص القانونية نجد أن المُشرِع الإجرائي يتطلَّب

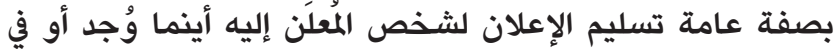

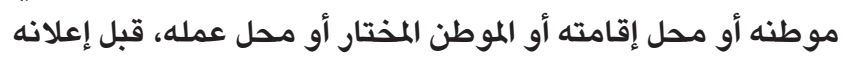

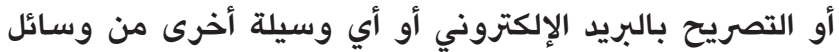

التقنية الحديثة.
ومن النص السابق نجد أن المُشِّع اقتصر على معالجة البريد

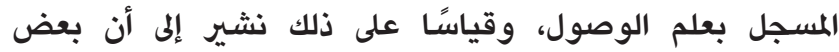

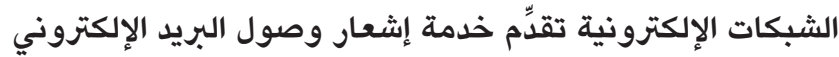
إلى مُستلمه. لذا، نرى أنه يجب الاقتصار على الإعلى الإعلان بواسطة

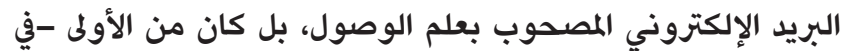

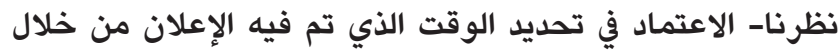

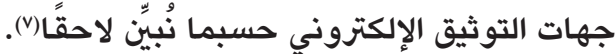
وننوه إلى استثناء الإعلان القضائي الإلكتروني في مجال الإنيا لأحوال الشخصية من هذه الأحكام، حيث نظّم القانون الاتحادي رقم

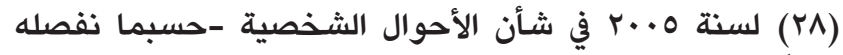
لاحقًا- كل ما يتعلق بالإعلان (التقليدي أو الإلكتروني) في مسائل الإن الإن

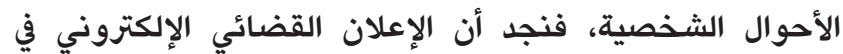

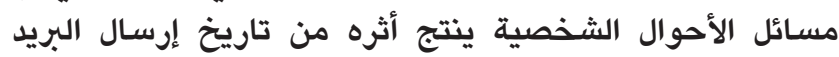
الإلكتروني، وليس من تاريخ وصول إشعار بالوصول، حسبما جاء بقانون الإجراءات المدنية، وبموجب مالئ ما سنفصله لاحقًا.

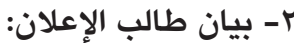
وفقًا للمادة (V) من قانون الإجراءات، يجب أن تشتمل ورقة الإعلان على اسم طالب الإعلان، ولقبه، ومهنته أو وظيفته،

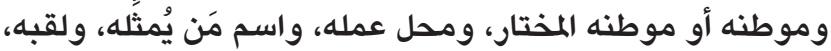
ومهنته أو وظيفته، وموطنه، ومحل عمله إن كان يعمل لغيره.

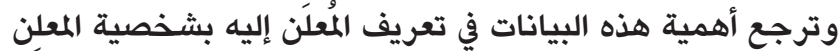

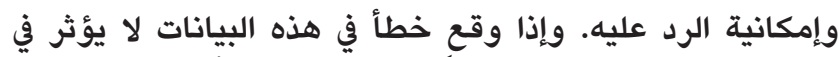
صحة الورقة طالما لا يثير الشكَّ حول شخصية وانية المُعلن.

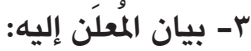

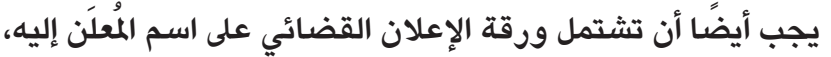
ولقبه، ومهنته أو وظيفته، وموطنه أو موطنه المختار، فيان لم

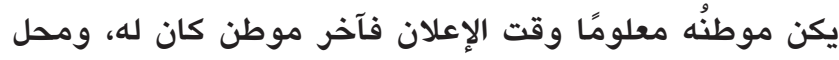
عمله. فإن لم يكن له موطن معلوم وقتَ الإعلان يجب أن تتضمَّن الورقة

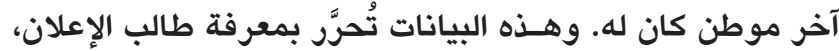

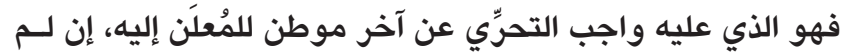
يكن له موطن معلوم. وبيانات المُعلَن إليه تهدف مولى إلى التعرف إليه، وتيسير مهمة القائم

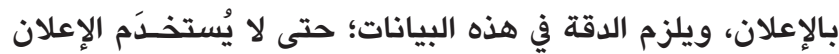
وسيلةً للتضليل وضيـاع حقــوق المُعلَن إليه(^).

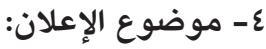
ويُقصد به الموضوع المطلوب إعلام الخصم به، فقد تكون الورقة

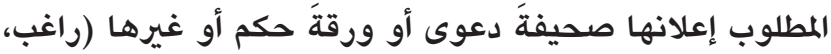

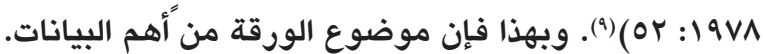

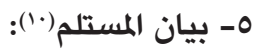

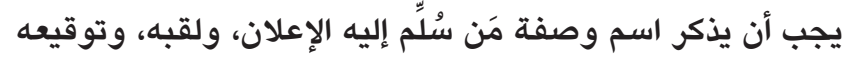

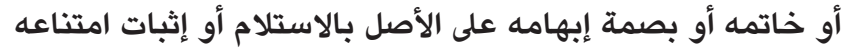

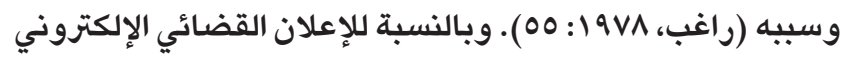

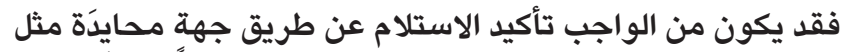
جهات التوثيق الإلكتروني. 


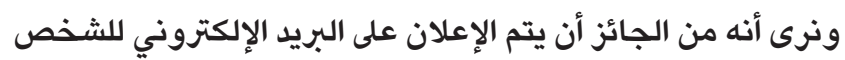
المطلوب إعلانه سواء كان البريد الإلكتروني تابعًا لعمله ألهانيا أو بريدًا

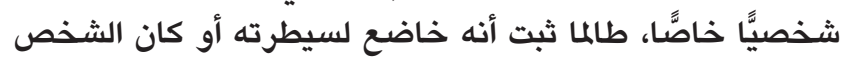

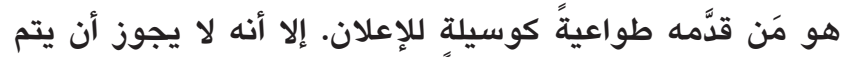

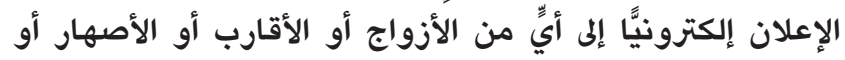

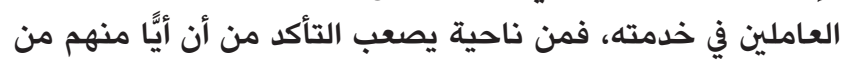

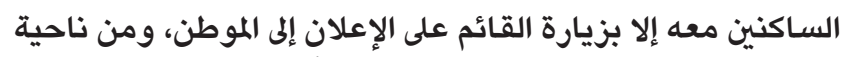

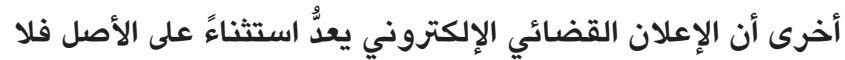
يجب التوسُّع فيه (Friedenthal ,Kane , Miller, 2015: 174)

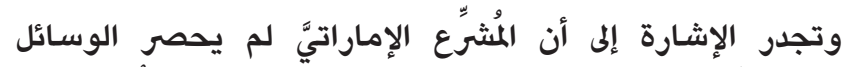

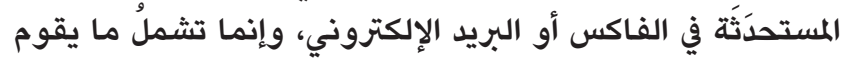

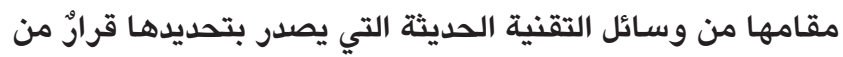

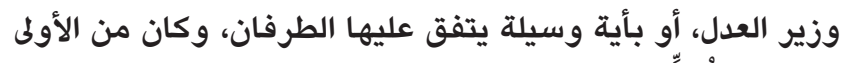

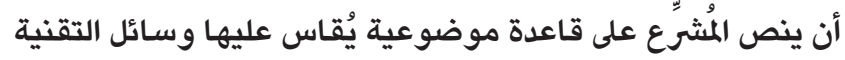

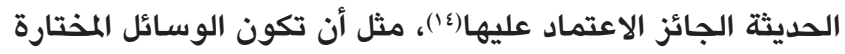

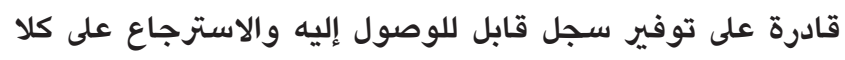

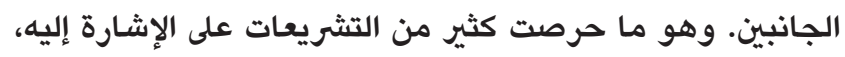

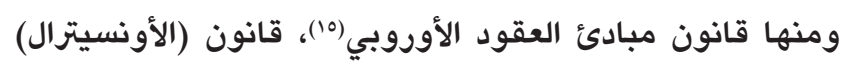

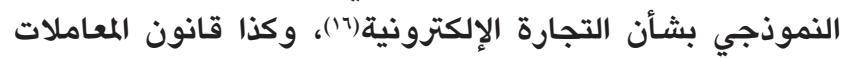

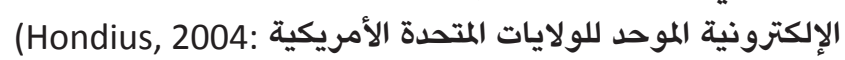

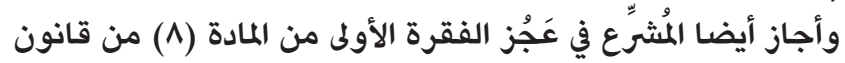

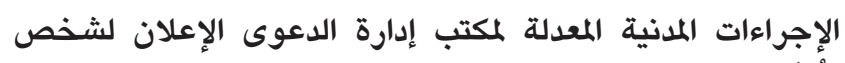

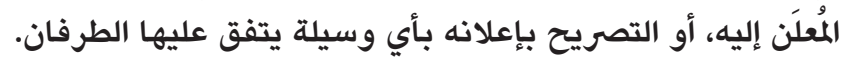

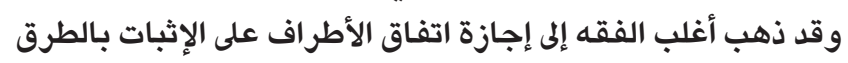

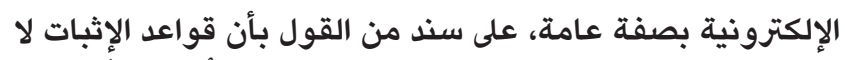

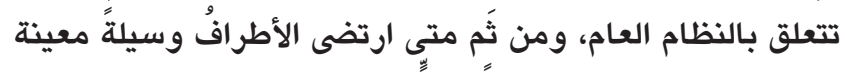

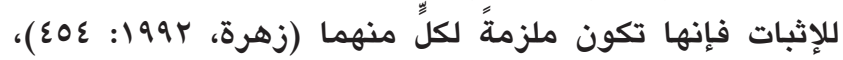

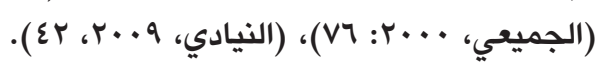

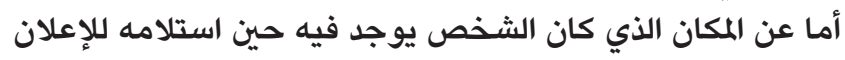

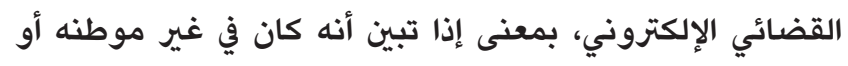

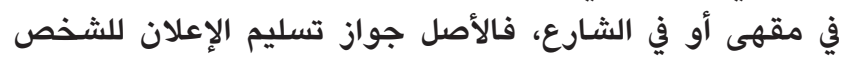

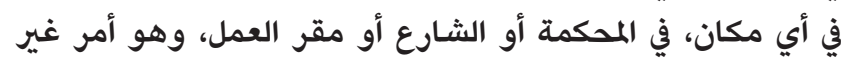

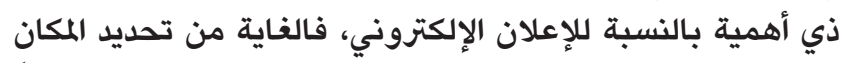
تكون في الإعلان التقليدي، بأن يراعِيَّ القائم بالإعلان الإندان اللباقةً

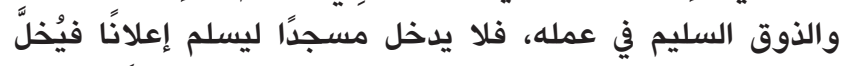

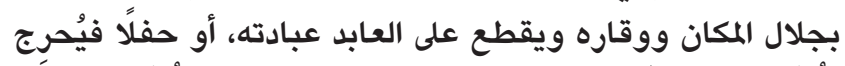

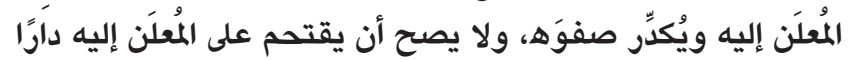

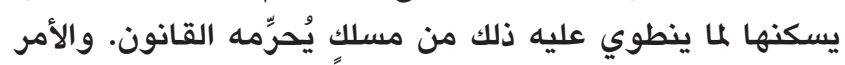

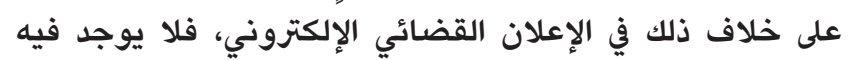

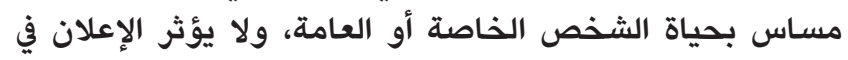
مكان وجوده(1)،. ومن ناحية أخرى فلن يُضطرَّ القائم بالإعلان الإن الخان

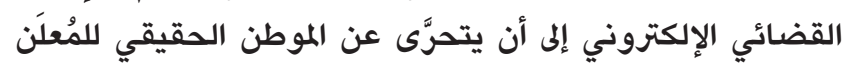

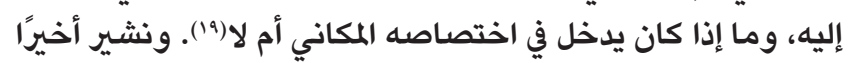

والمُعلَن إليه قد يكون شخصًا طبيعيًا وقد يكون شخصًا

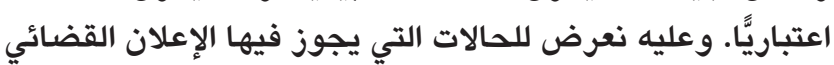
الإلكتروني إلى الشخص الطبيعي، ثم إعلان الشخص الشئ الاعتباري.

أولاً- الشخص الطبيعي:

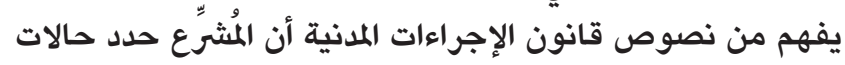

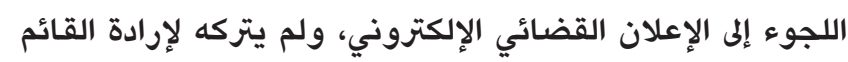

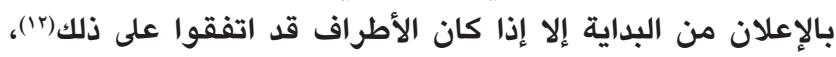

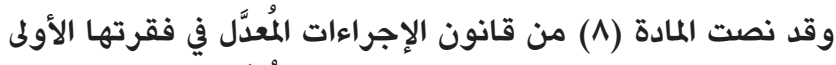

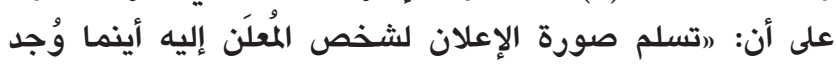

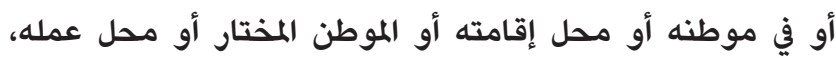

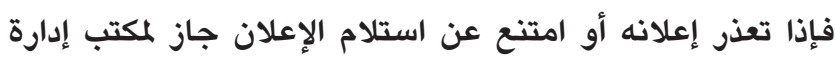

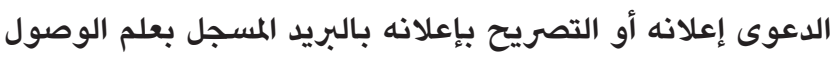

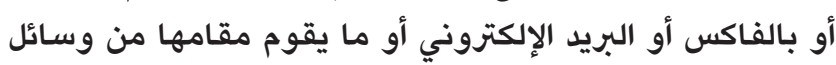

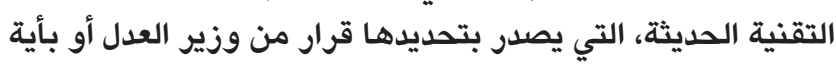
وسيلة يتفق عليها الطرفانه.

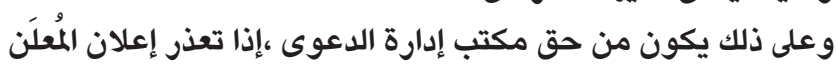

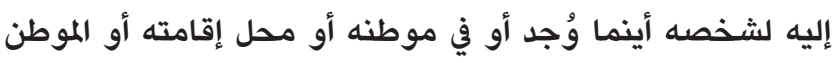

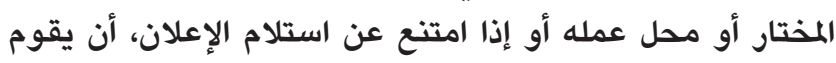

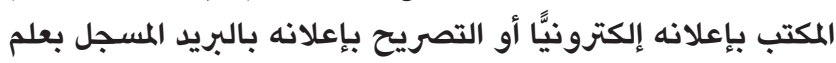

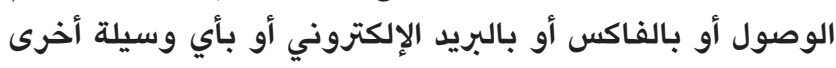

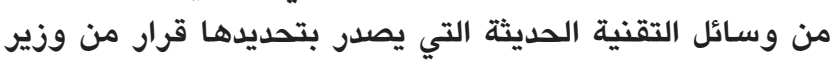
العدل أو بأية وسيلة يتفق عليها الطرفان التفان. ونصت أيضا المادة (^) من قانون الإجراءات المعدل في فقرتها إنها

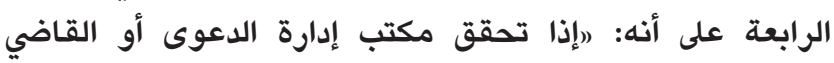

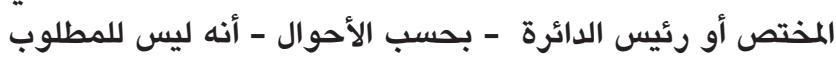

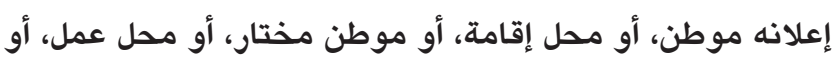

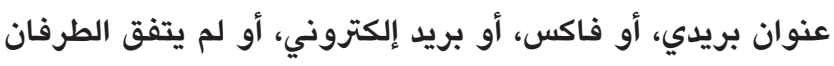

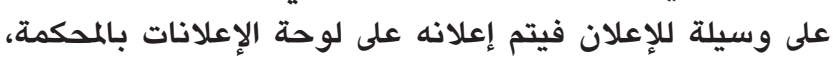

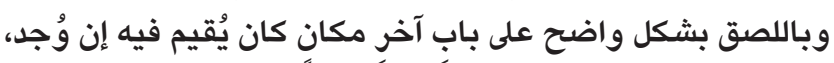

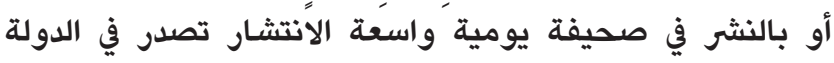

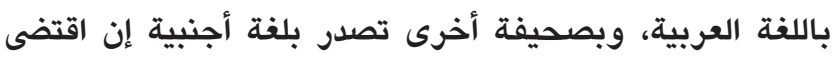

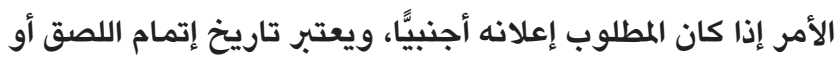
النثر تاريخًا لإجراء الإعلان)، إلهان.

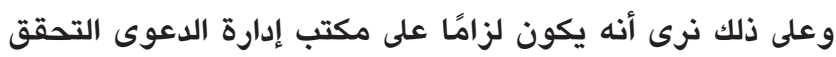

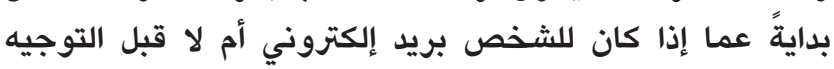

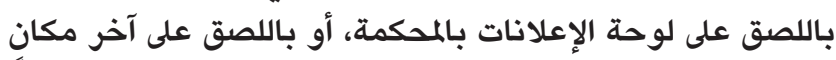

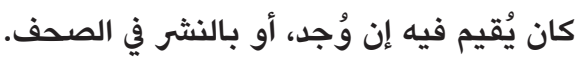

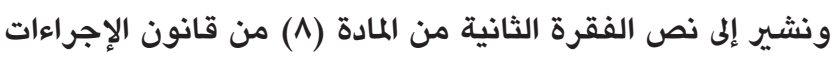

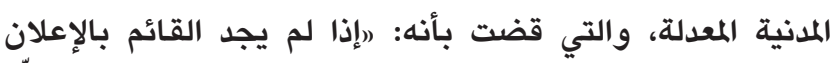

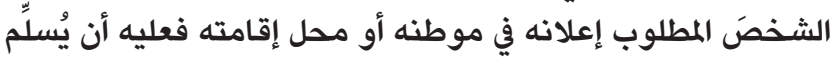

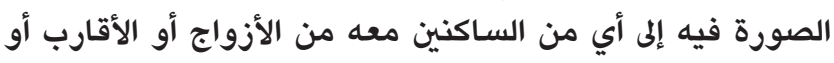

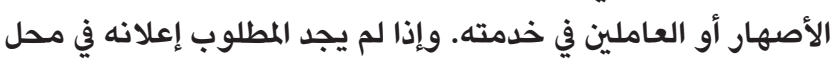

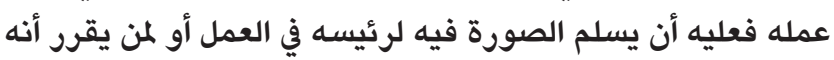
من القائمين على إدارته أو من العاملين فيه)، 
وكان من الأولى النص على إعلان الأشخاص الاعتبارية العامة

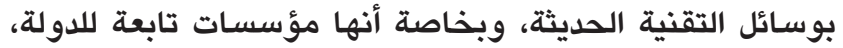
ويمكن إلزامها بنظام بريدي إلكتروني يحقق سهولة الإعلان ويضمن وصوله في أسرع وقت. وقد أخذ بذلك المشرع الكويتي

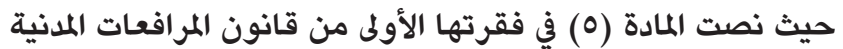

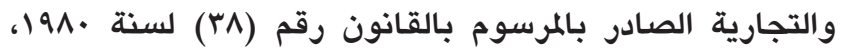
المعدل بالقانون رقم (YT) لسنة 10 إب، على أنه: "كل إعلان -ما لم ينص القانون على خلاف ذلك- يكون بواسطة مندوبي الإعلان أو مأموري التنفيذ وإلا كان باطلاً ويكون تصرير الإعلان بمعرفة الطالب، أو بناءً على تعريفه بواسطة ضابط والإن باطئ الدعاوى. وعلى الخصوم أو وكلائهم بذل المعاونة الممكنة لإتمام الإعلان.

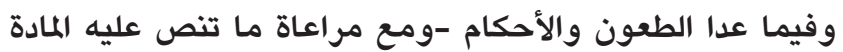

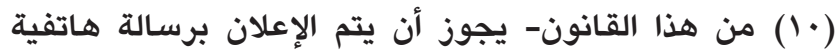
مكتوبة (فاكس) أو بأي وسيلة اتصال إلكترونية قابلة لحفظه

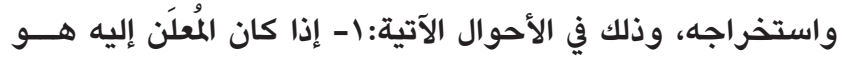

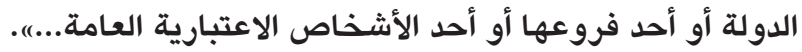

r- إعلان الأشخاص الاعتبارية الخاصة:

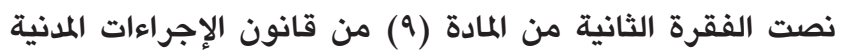
المعدلة على أنه فيما عدا ما نُص عليه في قوانين خاصة النه تسلم

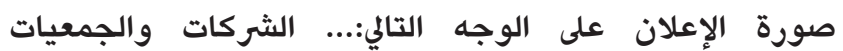
والمؤسسات الخاصة وسائر الأشخاص الاعتبارية الخاصة: تسلم

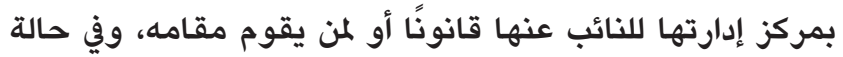
عدم وجودهما تسلم صورة الإعلان لأحد موظفي مكتبيهما فإذاذا

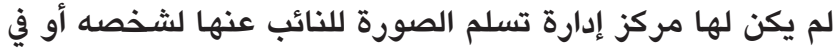

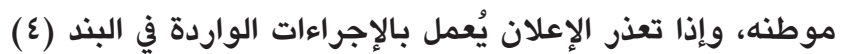

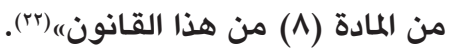
وبحسب النص المتقدم يكون الأصل أن يتم إعلان الشركات

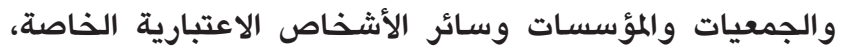
بتسليم صورة الإعلان بمركز إدارتها للنائب عنها قانونًا، أو لمن يقوم مقامه، وفي حالة عدم وجودهما تسلم صورة الإعلان لأحد موظفي مكتبيهما، فبإذا لم يكن لها مركز إدارة تسلم الصورة للنائب عنها لشخصه أو لمن في موطنه، على أن يكون الإعلان في هذاذ إنها

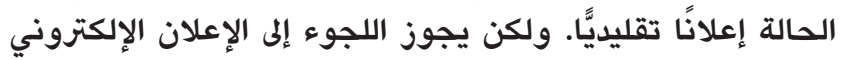
إذا ثبت لمكتب إدارة الدعوى أو القاضي المختص أو رئيس الدائرة

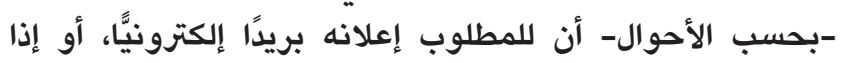

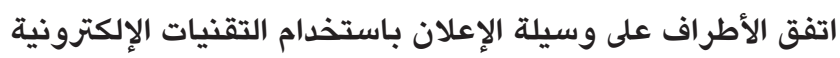
الحديثة.

الوقت الذي يجوز فيه إجراء الإعلان القضائي الإلكتروني: يثار التساؤل عن الوقت الجائز في توجيه الإعلان الإلكتروني، فقد الإند

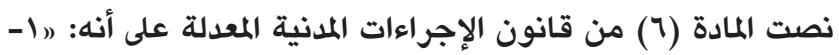

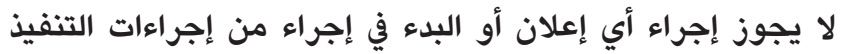
بوساطة القائم بالإعلان أو التنفيذ قبل الساعلاعة السباء السابعة صباحا، ولا بعد الساعة الثامنة مساء، ولا في أيام العطلات الرسمية إلا الإلات

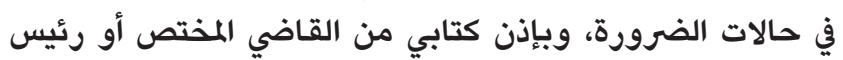

إلى أن المُشّرِع ألغَى العمل بنص المادة (Y) من قانون الإجراءات

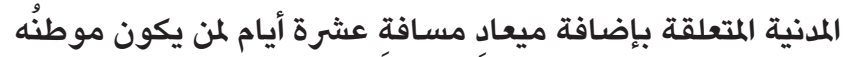

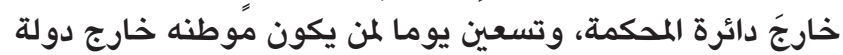

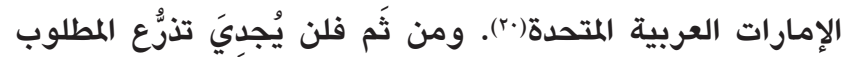
إعلانه بوصول الإعلان القضائي الإلكتروني إليه وهو بموطن تهنه

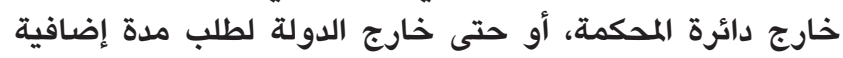

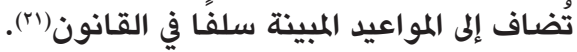
الإعلان الإلكتروني في مسائل الأحوال الشخصية: ثمة استثناء بخصوص الإعلان الإلكتروني في مجال الأحوال

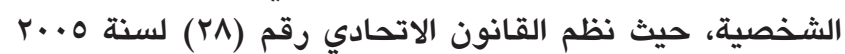

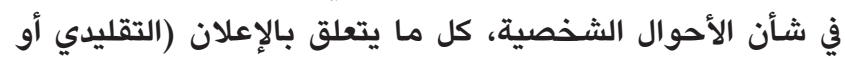

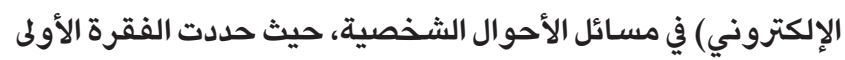

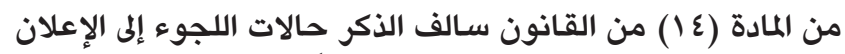

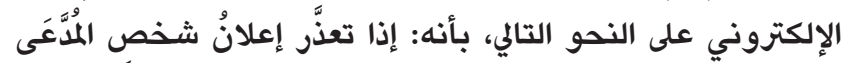

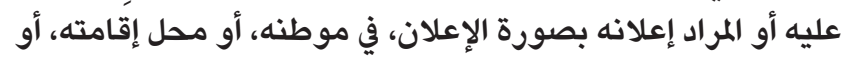

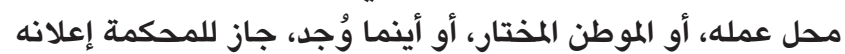

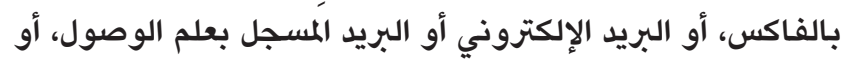

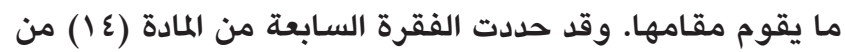

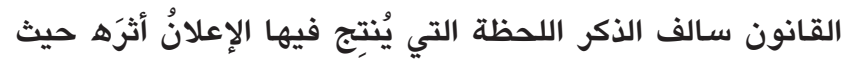

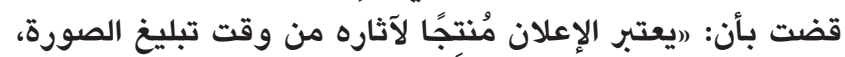

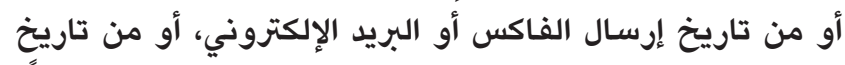

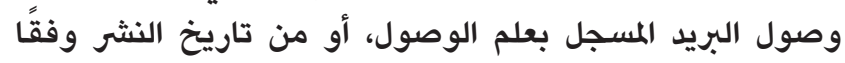

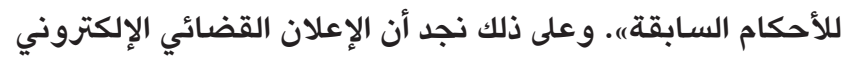

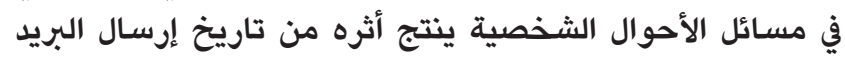
الإلكتروني، وليس من تاريخ وصول إشعار بالوصول حسبما جاء الاء

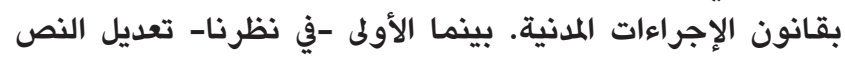

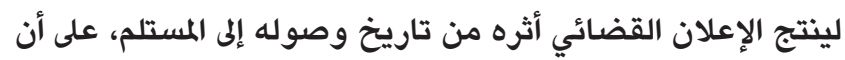

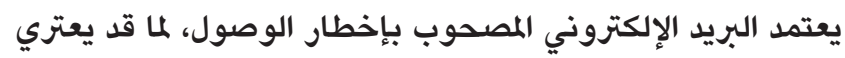
محتوى البريد الإلكتروني من مشكلات تقنية، أو تغير في المحتوىى، لمدي،

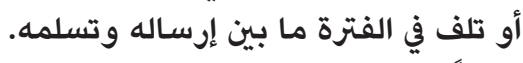

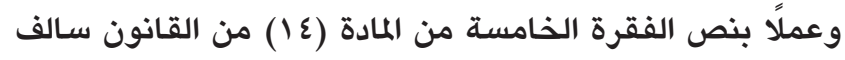

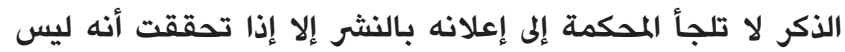

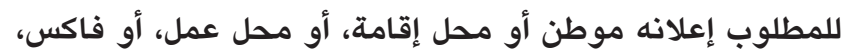

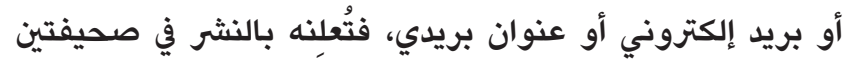

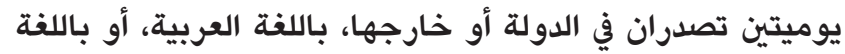

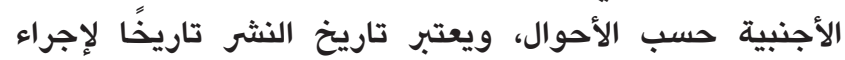

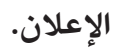

ثانيًا- الشخص الاعتباري: ا- إعلان الأشخاص الاعتبارية العامة: يُقصد بالأشخاص الاعتبارية العامة، الدولة والمصالح الإعتارية العامة: العامة

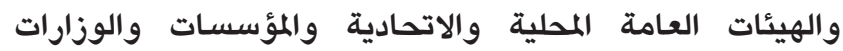

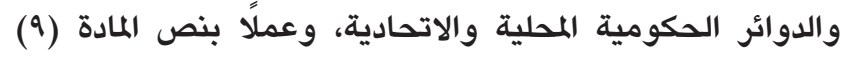
من قانون الإجراءات المدنية المعدلة، يسلم الإعلان إلى من يمثلها والماتها

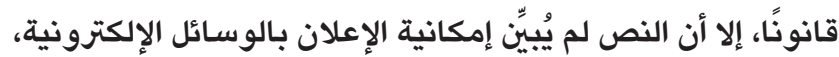


في حروف أو أرقام أو رموز أو أي علامات أخرى، تثبّت على دعامة

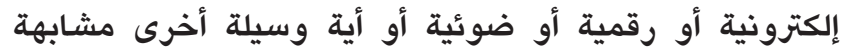

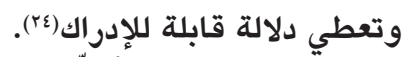

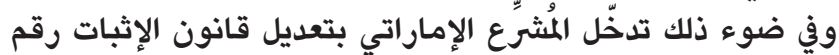

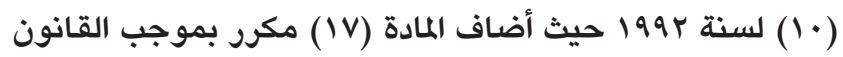

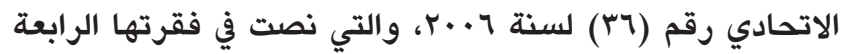
على أنه: (اللكتابة الإلكترونية والمحررات الإلكترونية والسجلات

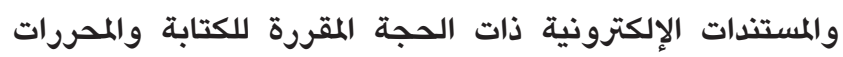

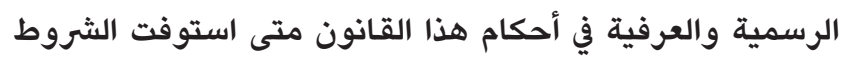

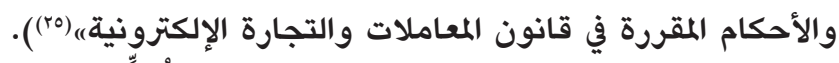

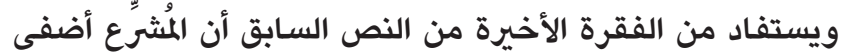

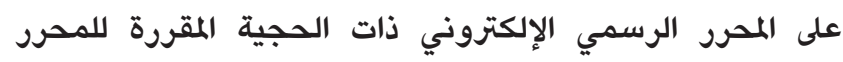

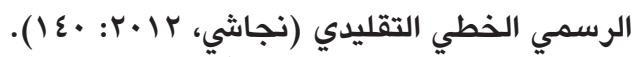

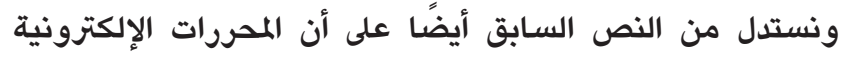

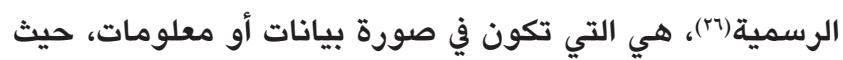

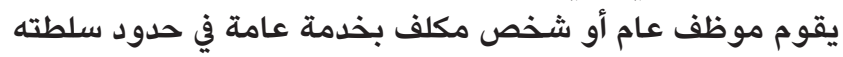

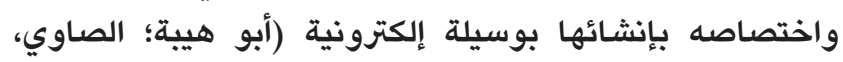

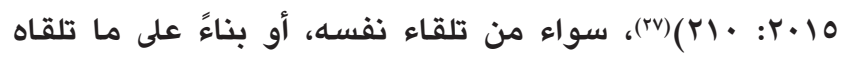

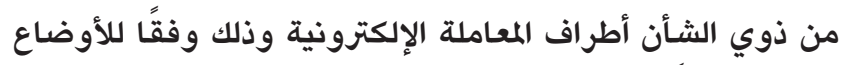

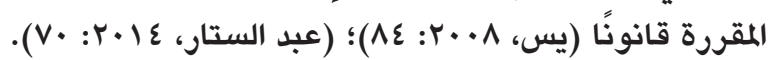

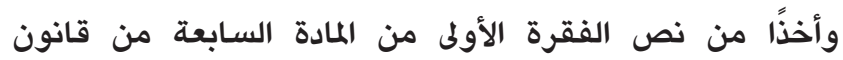

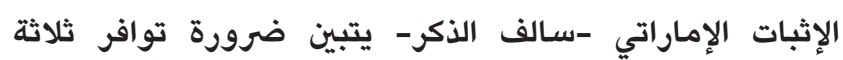

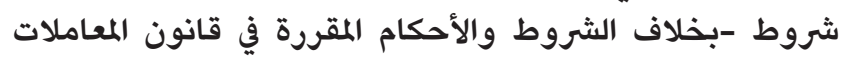

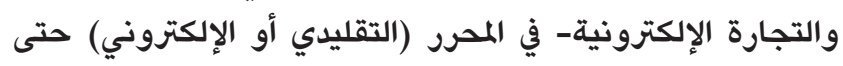

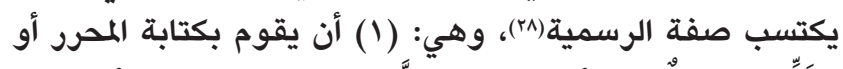

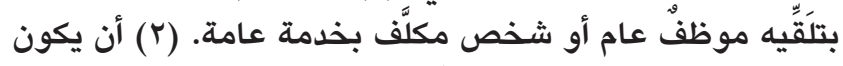

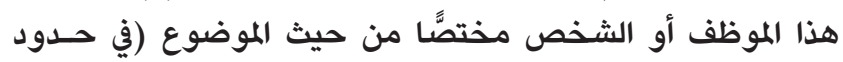

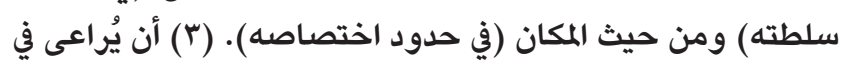
توثيق المحرر الأوضاع التي قررها المان القانون.

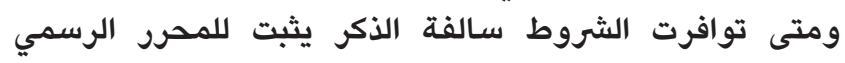

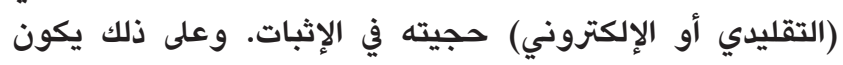

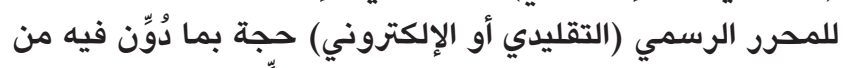

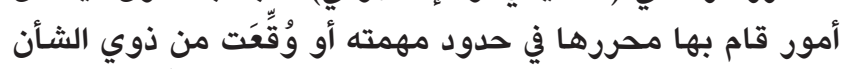

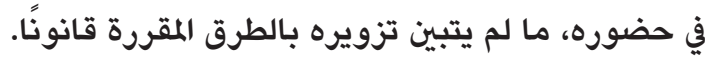

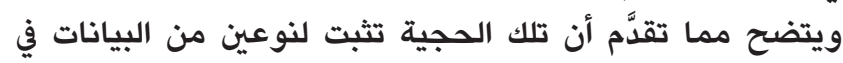

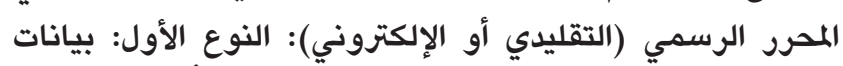

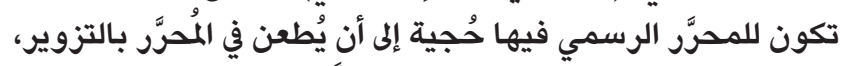

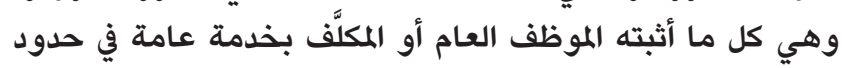

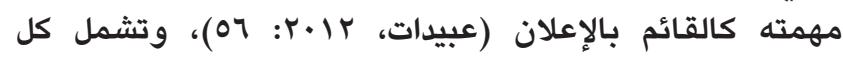

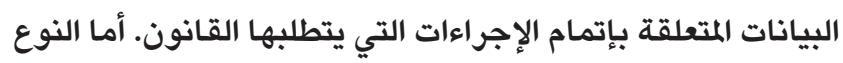

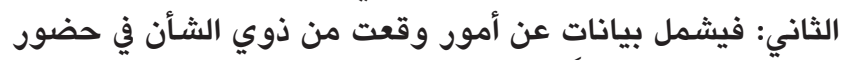

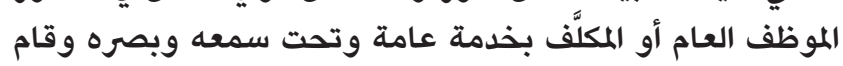

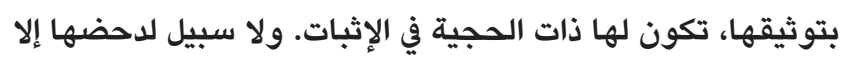

بالطعن بالتزوير (9a). (19). وقد ورد بقضاء المحكمة الاتحادية العليا أنه: "امن المقرر أن

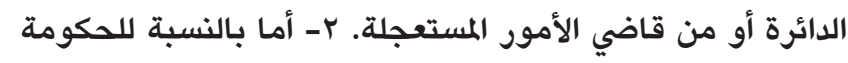

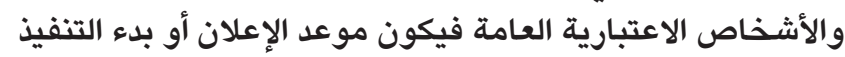

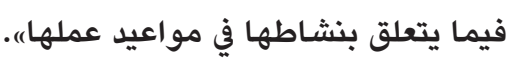

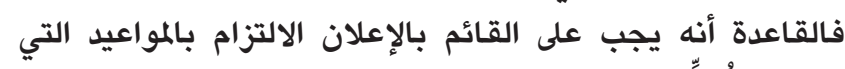

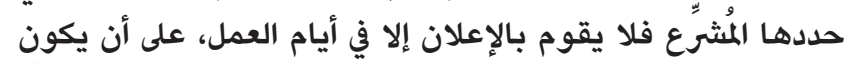

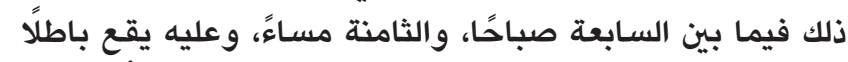

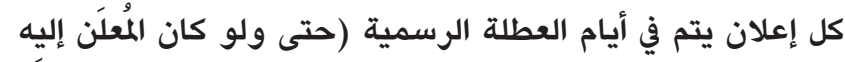

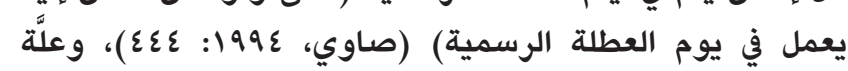

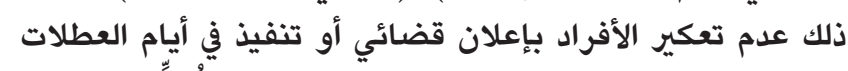

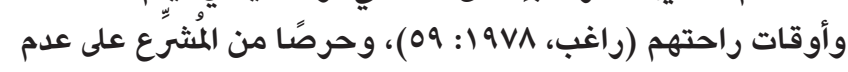

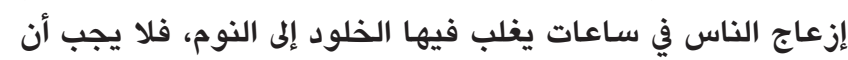

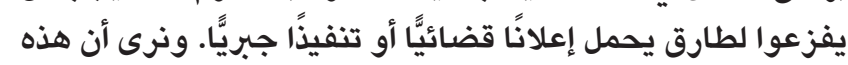

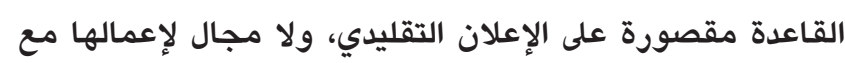

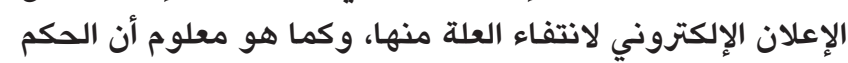

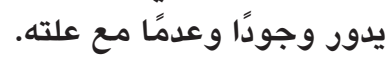

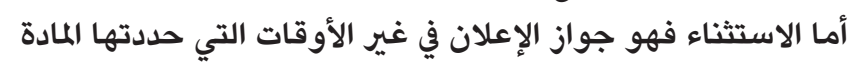

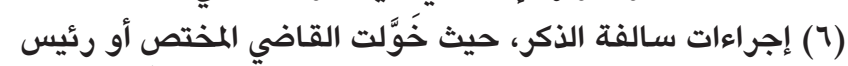

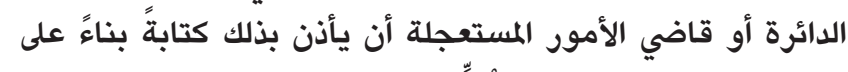

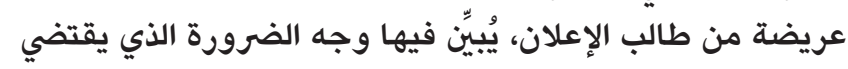

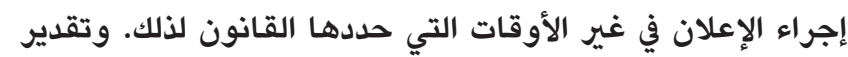

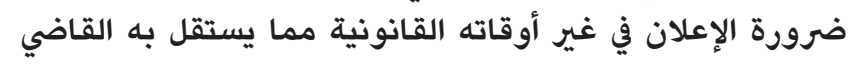

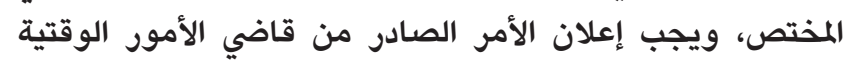

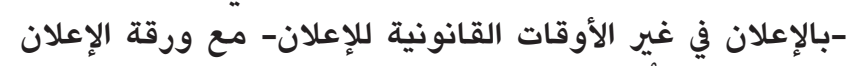

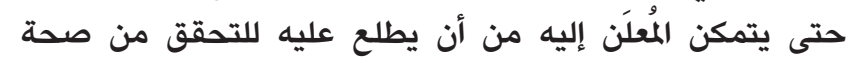

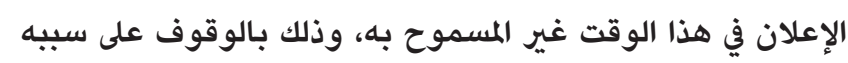

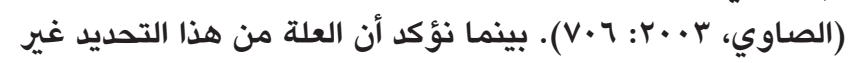

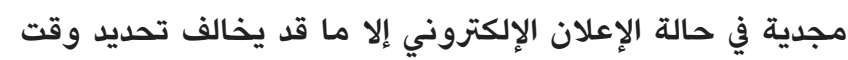

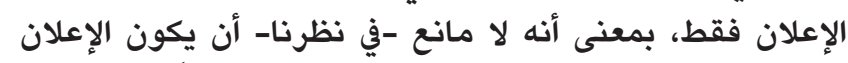

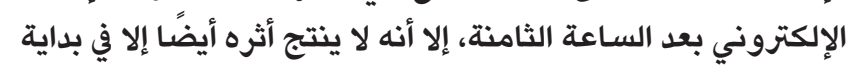
اليوم التالي في السابعة صباحًا.

الفرع الثانيـِ حجية الإعلان القضائي الإلكتروني في الإثبات:

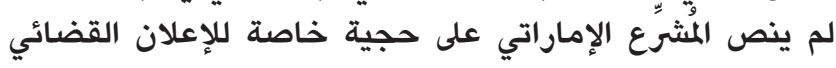

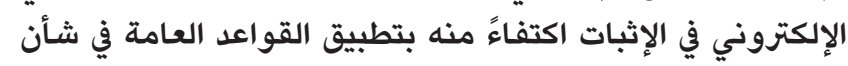

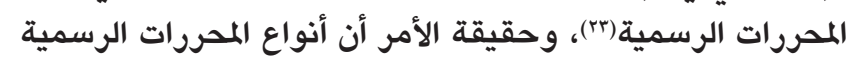

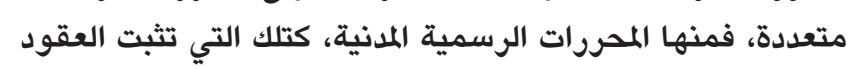

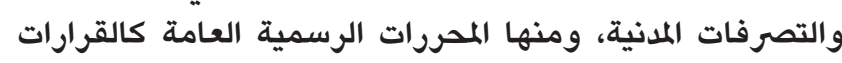

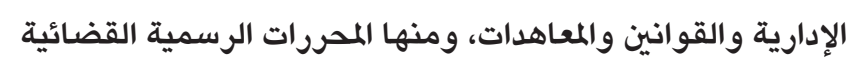

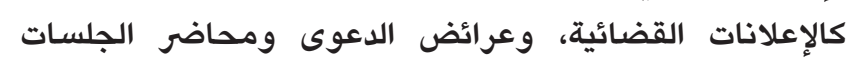
والأحكام، وغيرها، إلا أن الجامع المشترك المترك بينها جميعًا كونها

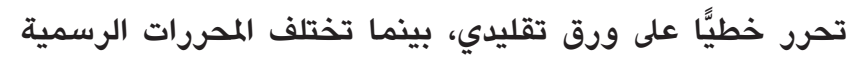
الإلكترونية كونها تتم عن طريق وسيط توليط إلكتروني.

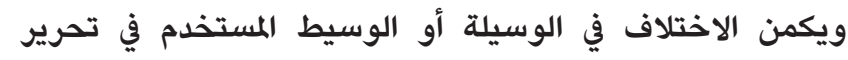

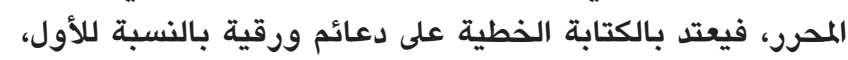

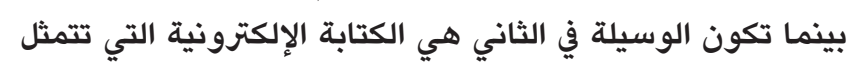




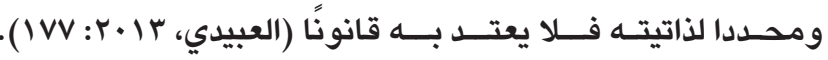

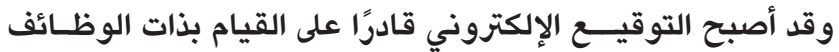

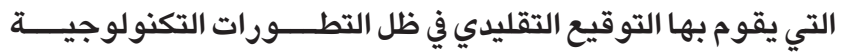

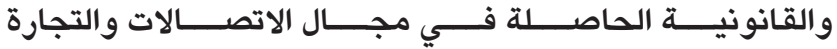

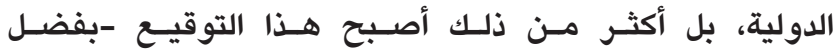

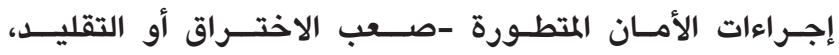

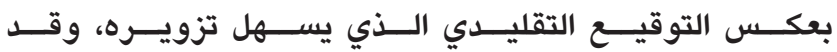

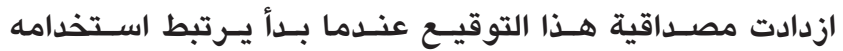

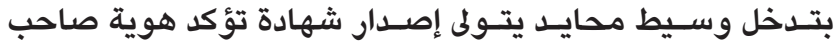

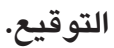

الفرع الرابع - التوثيق الإلكتروني ودوره في تفعيل العمل بالإعلان

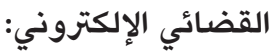

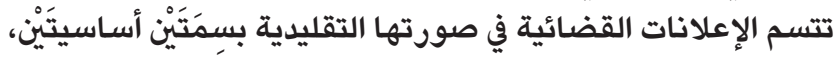

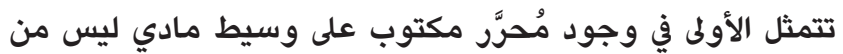

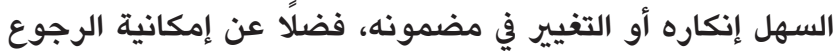

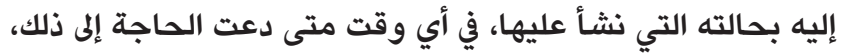
وتتعلق السمة الثانية بوجود توقيع يُزيِّل المستند، يُفيد الإقرارَ

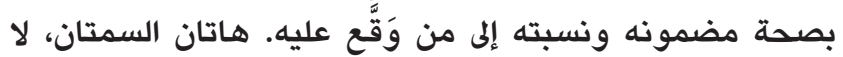
وجود لهما في المعاملات الإلكترونية بنفس الصورة المتعارَف عليها

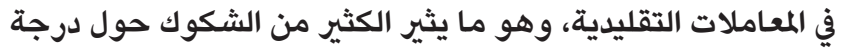

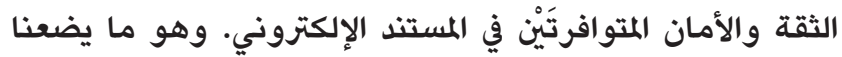
أمام المشكلة الكبرى التي تتصل بمدى الإن قدرة الإعلان القضائي

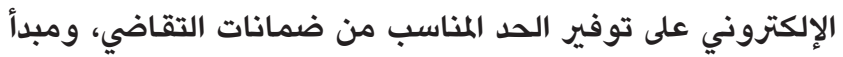

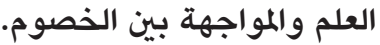
ونظرًا لأهمية المعاملات الإلكترونية بما بالثا فيها الإعلانات القضائية

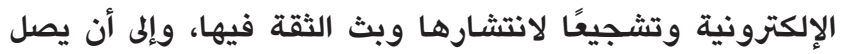

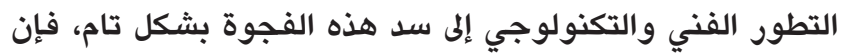

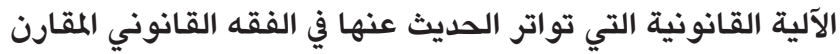

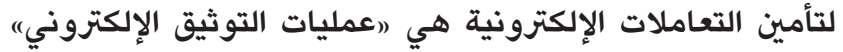

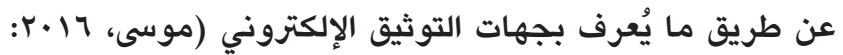

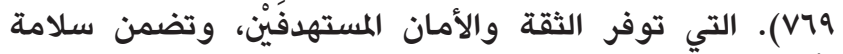

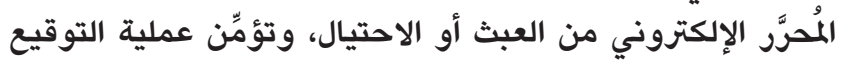

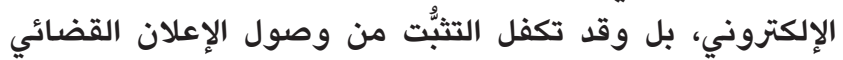
الإلكتروني إلى المطلوب إعلانه.

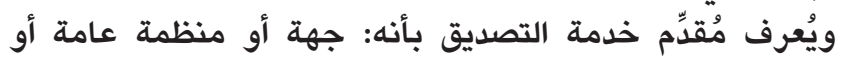
خاصة مستقلة محايدة تقوم بدور الوسيط بين المتعاملين لتوثيق تعاملاتهم الإلكترونية بإصدار شهادات إلكترونية، ويُطلَّق على الغير الذي يتولى عملية التصديق "مُقدِّم خدمات التصات التصديقية prestataire de services de certification

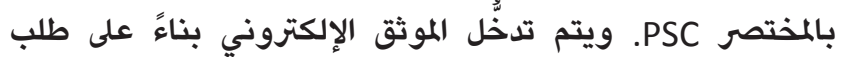
شخصين أو أكثر؛ بهدف إنشاء وحفظ وإثبات الرسائل الإلكترونية

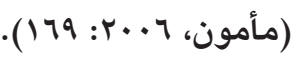

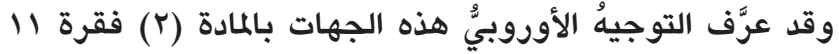
بأنها: ״كل شخص قانوني طبيعي أو معنوي يُصدِر شهادات
محضر الإعلان -مذكرة التبليخ- المتضِّمن لإجراءات الإعلان التي

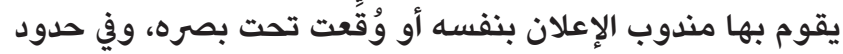
مهمته من المحررات الرسمية التي أسبخ القانونُ الحجيَّةَ المطلقةَ

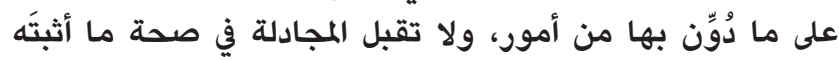
مندوب الإعلان في أصل الإعلان ما لمان لم يُطعن على هذه البيان فيانات

$$
\text { بالتزوير)(·"). }
$$

الفرع الثالث- قواعد إسناد الإعلان القضائي الإلكتروني إلى مُنشئه ومُستقبله: قدَّمنا أنَ المُشَرِّع الإجرائي اقتصر على معالجة البريد المصحوب

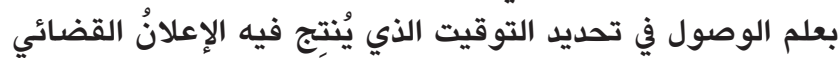

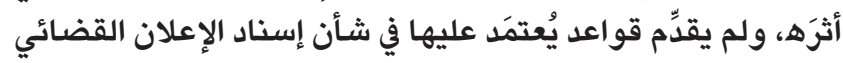

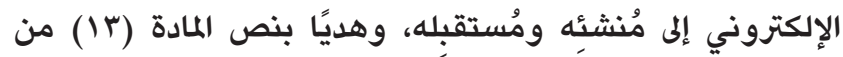

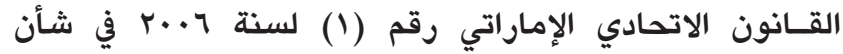

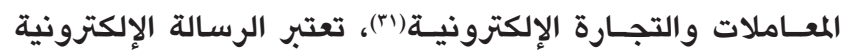

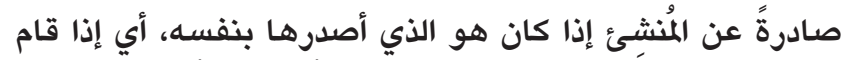

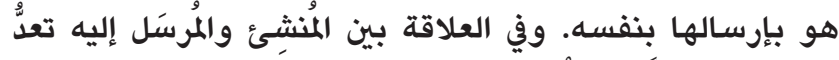

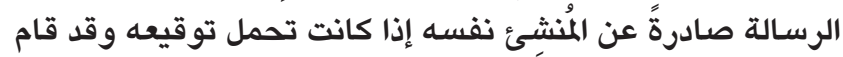

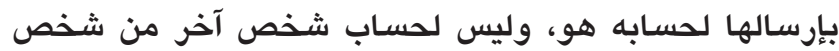

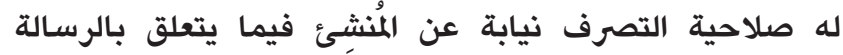

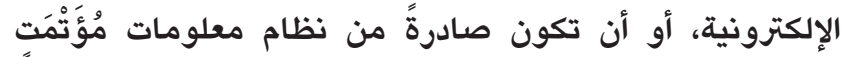

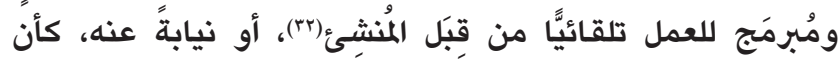

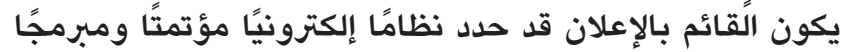

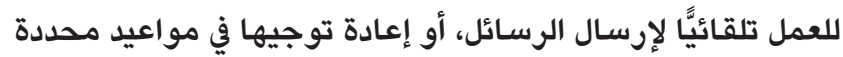

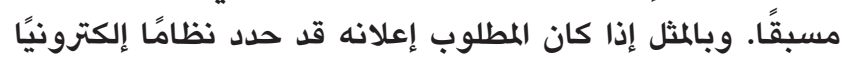

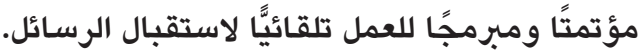

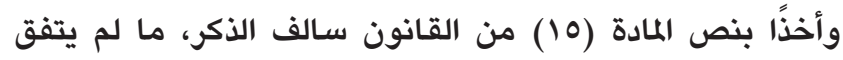
المنشئ والمرسل إليه على غير ذلك يكون إرسال المال الرسالة الإلكترونية المانية

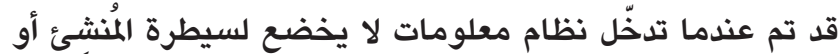
الشخص الذي أرسل الرسالة نيابة عن المُنشئ.

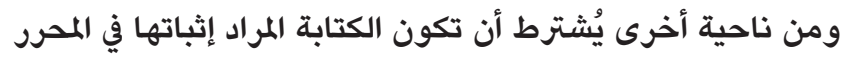

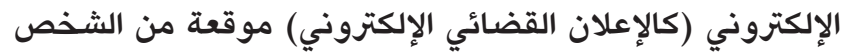

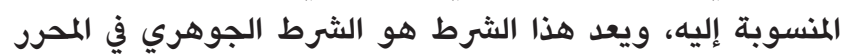

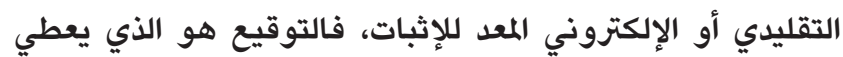

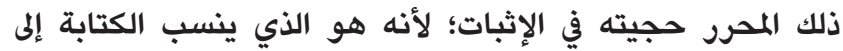

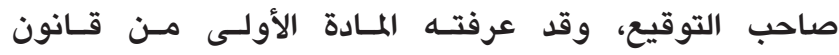

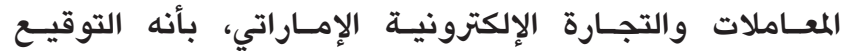

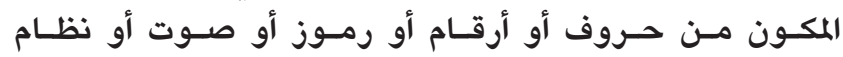

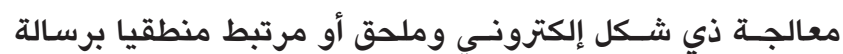

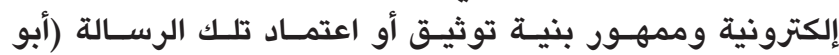

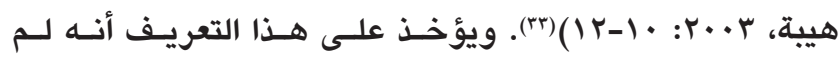

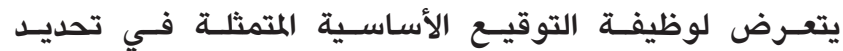

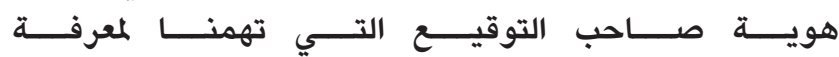

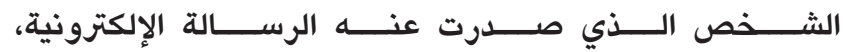

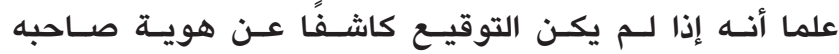


حاولنا في هذه الدراسة الموجزة أن نتناول موضوعًا غاية في

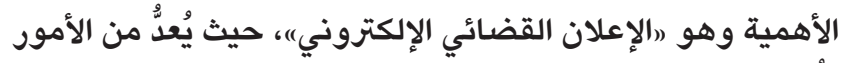

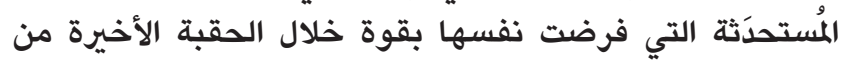

القرن العشرين.

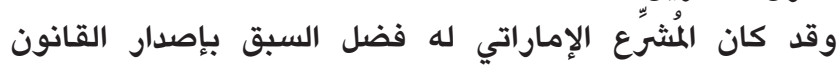

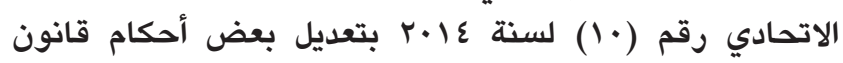

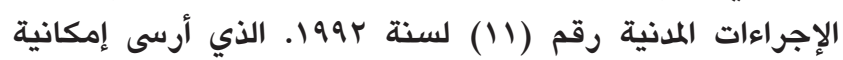

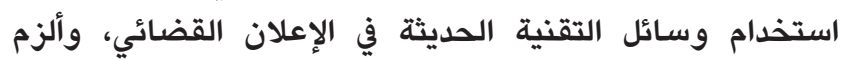

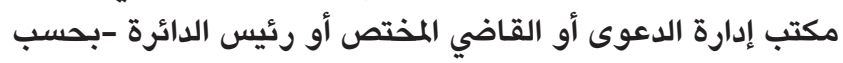

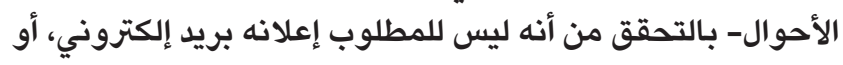

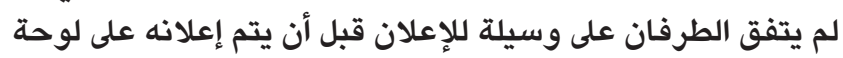
الإعلانات بالمحكمة، وباللصق، أو أو بالنشر.

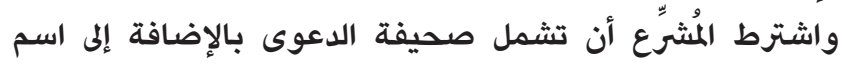

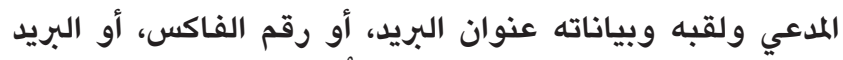

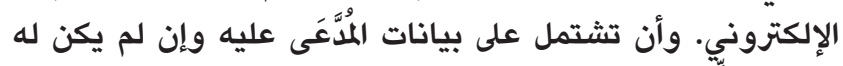

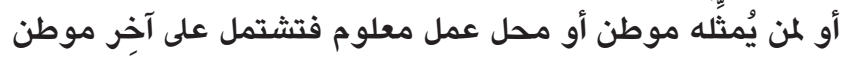

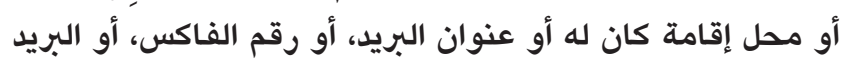
الإلكتروني. بينما يُثار التساؤل عن مدى إمكانية استخدام هذه الوسيلة بين

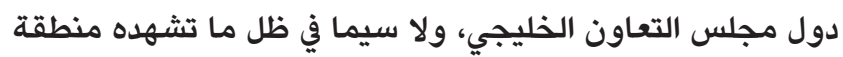

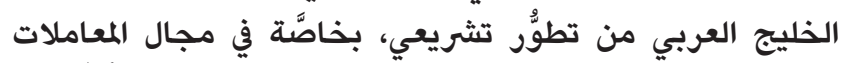

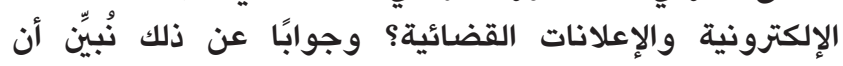

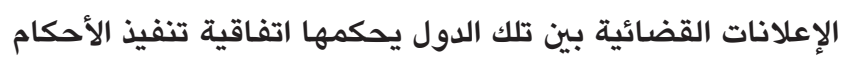

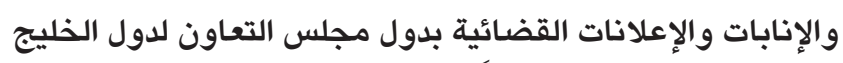

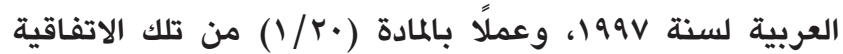

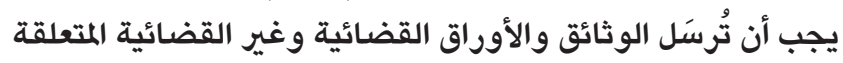

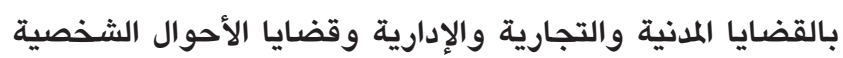

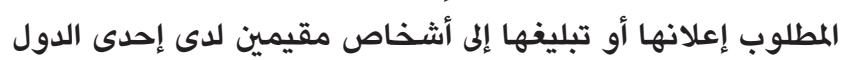

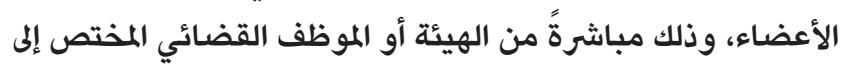

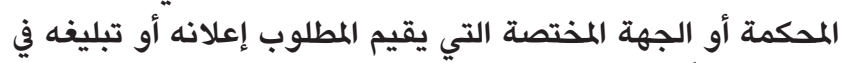

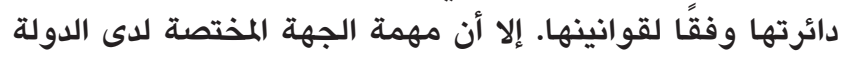

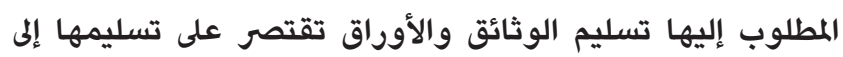

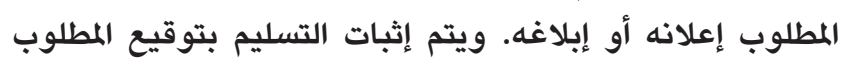

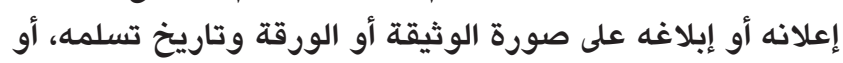

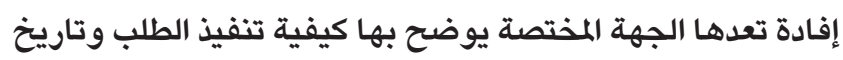

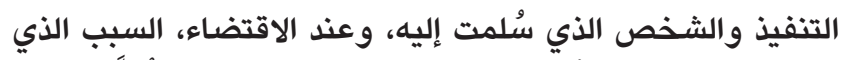

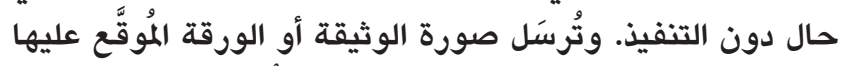

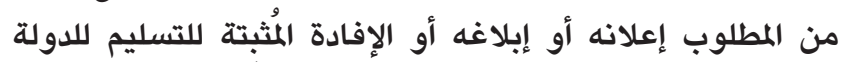
الطالبة مباشرة (99).

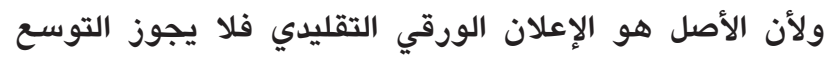

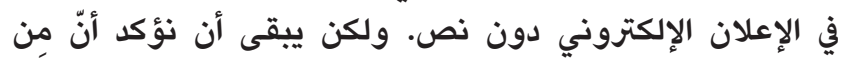

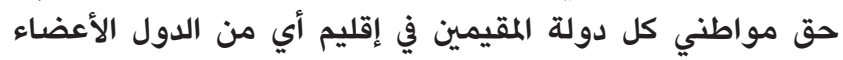

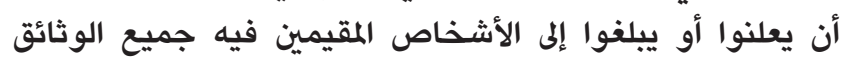

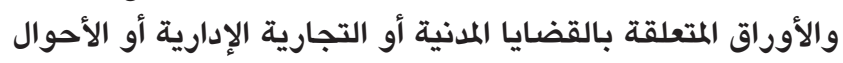

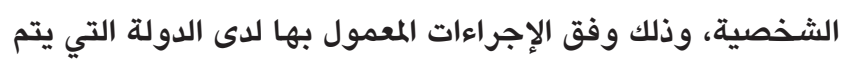

توثيق التوقيع الإلكتروني، أو يتولى تقديمَ خدمات أخرى مرتبطة

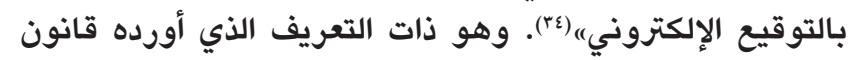

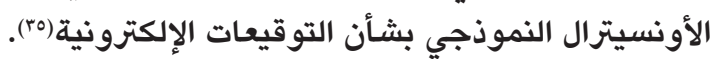

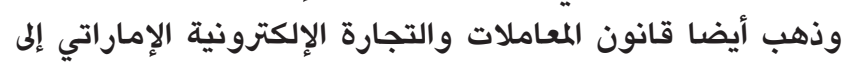

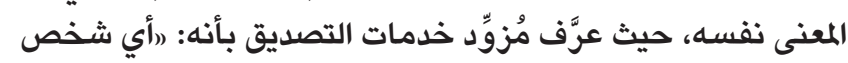

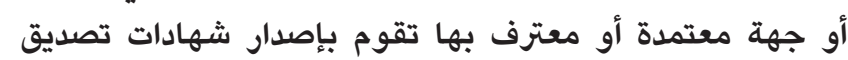

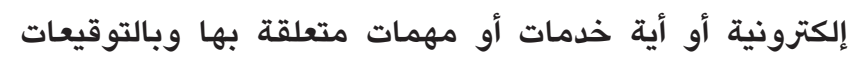

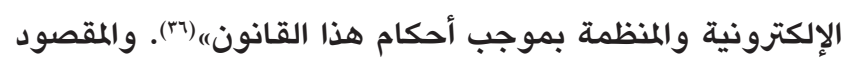
بالخدمات المرتبطة بالتوقيع الإلكتروني التقنيات التي تسمح

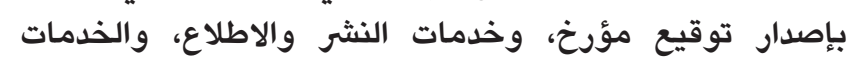

المعلوماتية الأخرى كالحفظ في الأرشيف (rv).

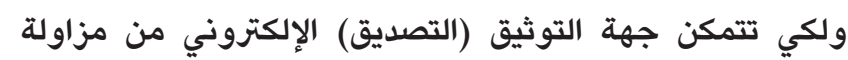

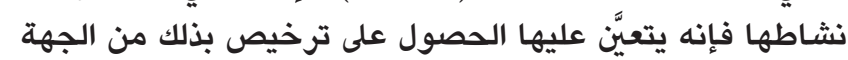

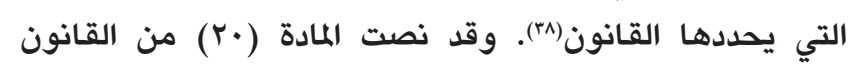

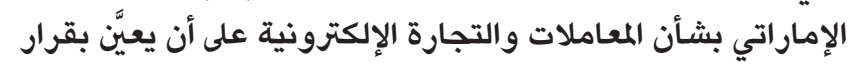

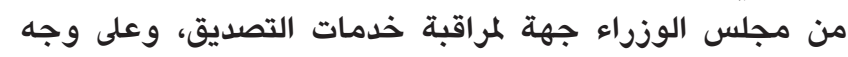

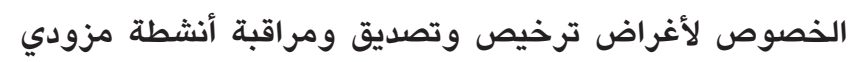
خدمات التصديق والإشراف عليها.

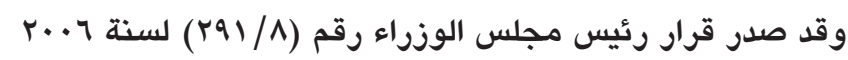

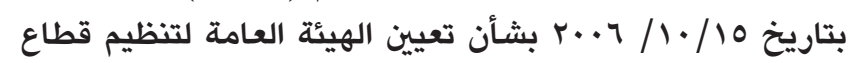

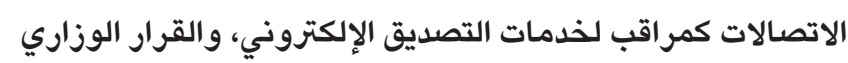

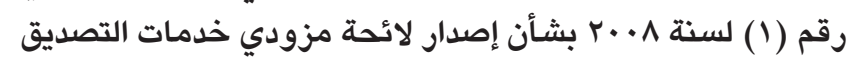
الإلكتروني. ومن العرض السابق نرى أنه من الممكن الاستفادة من خدمات جهات التوثيق الإلكتروني في تفعيل آلية الإعلانات القانه القضائية الإنية

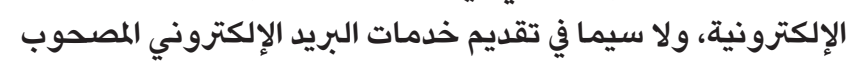

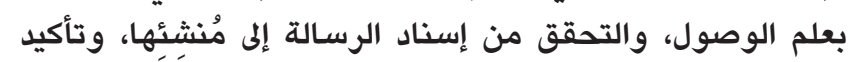

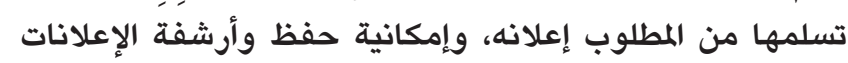

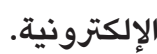
وقد يُناط بجهات التوثيق الإلكتروني مهمتان أخريان في غاية

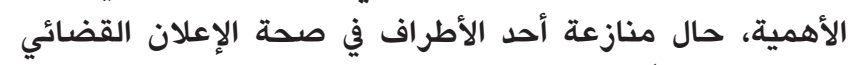

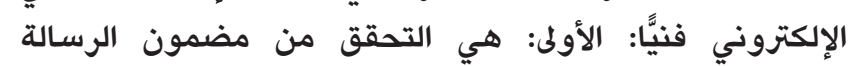

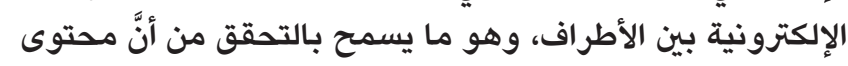

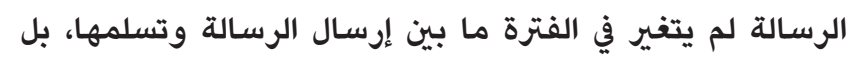

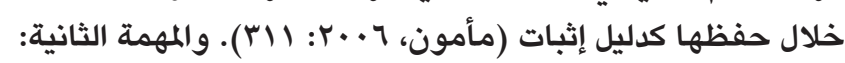

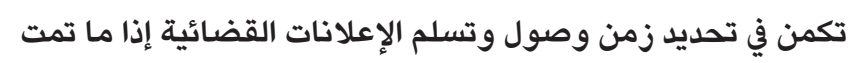

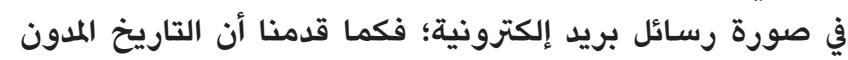

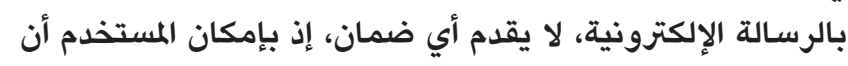

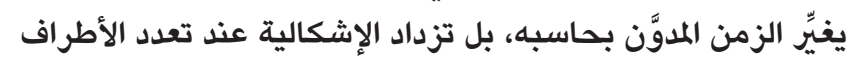

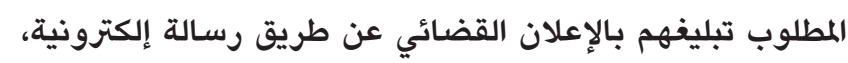

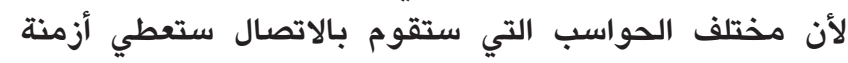

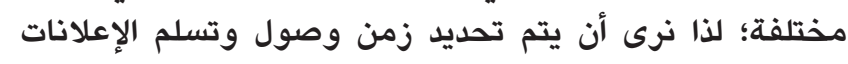
القضائية الإلكترونية من خلال جهات التوثيق. 
(1) وتأتي على رأس تلك المنظمات لجنة الأمم المتحدة للقانون

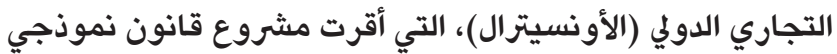

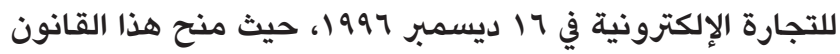

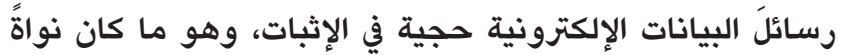

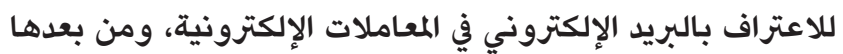

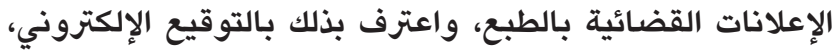

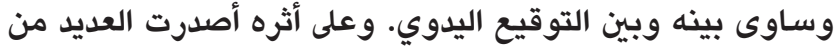

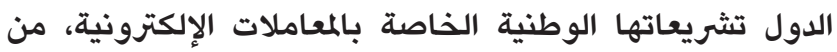
هذه الدول نذكر على سبيل المثال: إيطاليا (10 مارس الإس (199V)،

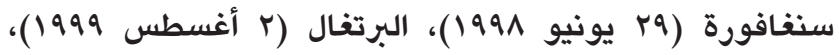

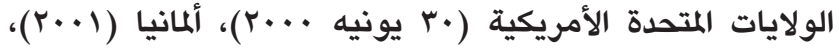

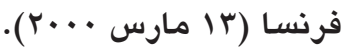

(r) لا سيما وقد سبقته إرهاصات ميلاد مضيئة بصدور قانون

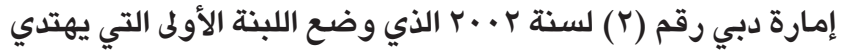

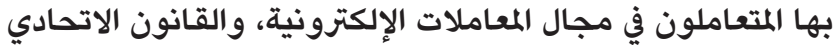
رقم ( () لسنة ج +. ب في شأن المعاملات والتجارة الإلكترونية.

(ץ) المادة الأولى من قانون المعاملات الإلكترونية الاتحادي رقم

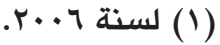

(ع) ومن ذلك حق الخصم في الاطلاع والرد على كافة أوراق

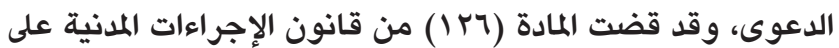

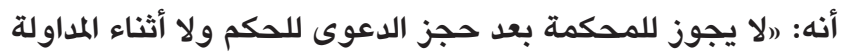
أن تسمع أحد الخصوم أو وكيله إلا بحضور خصمه، أو أو أن تقبل أوراقًا أو مذكرات من أحد الخصوم دون إطلاع الخاع الخصم الآخر عليها وإلا كان الإجراء باطلاًا).

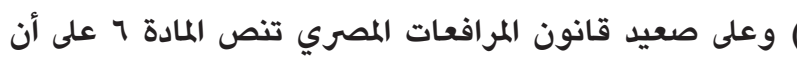

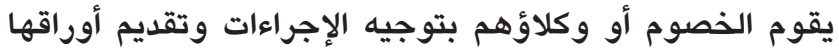

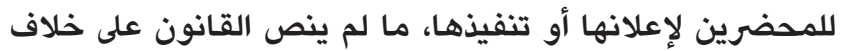
ذلك. فالأصل هو أن يحرر الخصم أو وكيله في الخصومة الخدان ورقانة

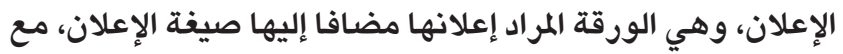
ترك مساحات للبيانات غير المعلومة لهم مقدَّمًا، والتي يستوفيها المحضر القائم بالإعلان، كتاريخ الإعلان، واسم المحضر، ولماني واسم من

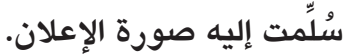

(1) بينما سمح المُشرِّع الإماراتي بقيد صحيفة الدعوى إلكترونيًّا

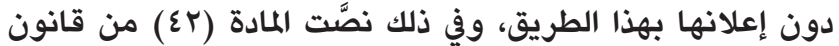

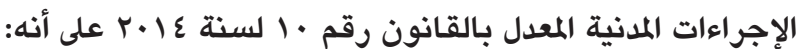

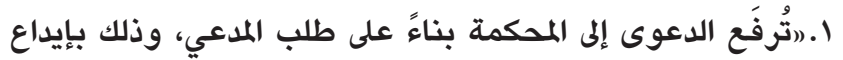
صحيفة دعواه لدى مكتب إدارة الدعوى، أو بقيدها إلكترونيًا. r.يجب أن تشتمل صحيفة الدعوى على البيانات الآتية:

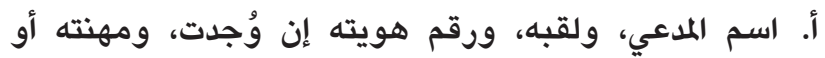
وظيفته، وموطنه، ومحل عمله، ورقم هاتفه، واسم مَن وَن

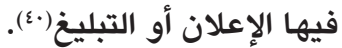

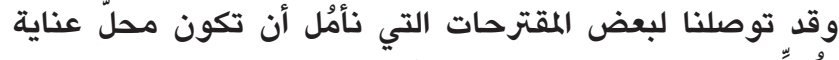

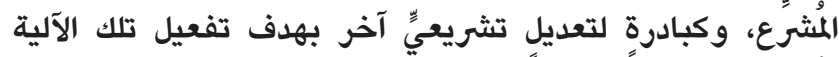
المستحدَثة: ا- نوصي الدول الأعضاء بمجلس التعاون لدول الخليج العربية

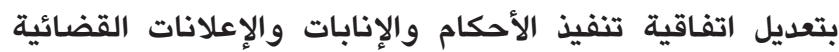
بدول مجلس التعاون لسنة 199V لإدخال آلية الإعلان القضائي

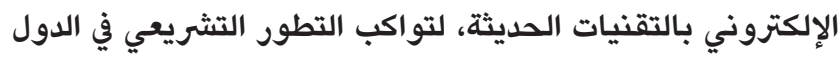
الأعضاء، بخاصة في مجال الإعلانات القضائية.

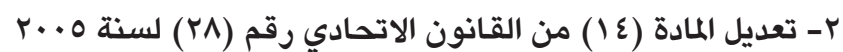

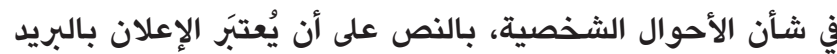

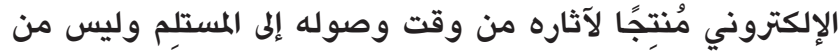

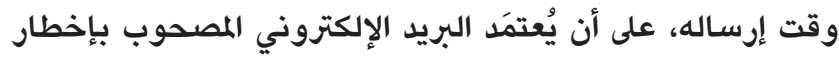

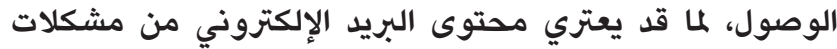

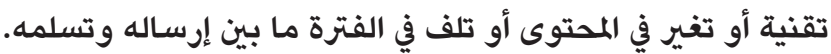

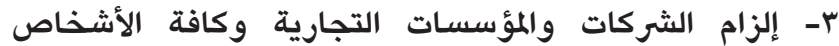

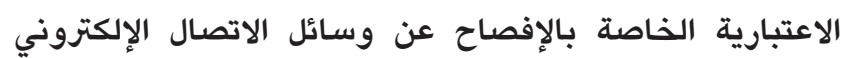

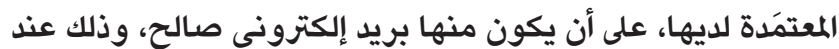

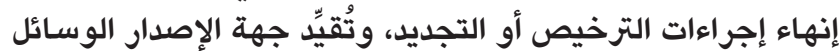

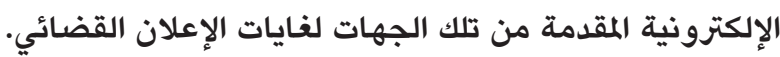
ع- إلزام مؤسسات الدولة وفروعها وكافة الأشخاص الاعتبات الاعتارية العامة بتسجيل وموافاة وزارة العدل بوسائل الاتصال الإلكتروني الإني المعتمَدة لديها، على أن يكون منها بريد إلكتروني.

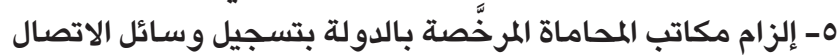

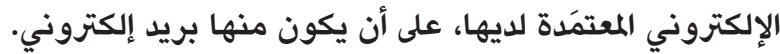

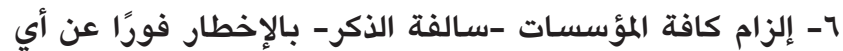

تعديل لبيانات الاتصال الإلكتروني المعتمَدة لديها.

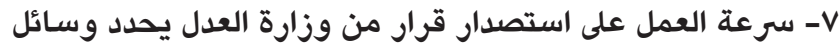

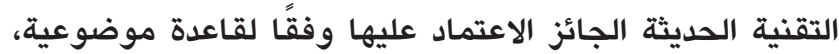
كأن تكون الوسائل المختارة قادرة على توفير سجل قابل للإن الوصول إليه والاسترجاع على كلا الجانبين. ^- أن تتولى وزارة العدل إعداد قاعدة بيانات تشمل عناوين البريد الإلكتروني ووسائل التقنية الحديثة المقدَّمة من الجهات تاعنات

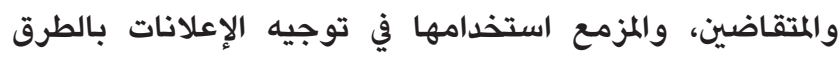

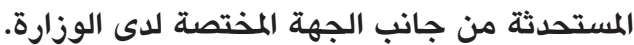

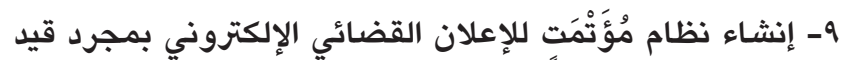
الدعاوى إلكترونيًّا. • ا- الاستفادة من خِدمات جهات الإتوات التوثيق الإلكتروني في ضبط

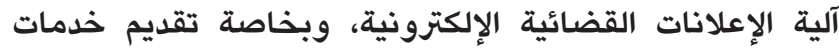

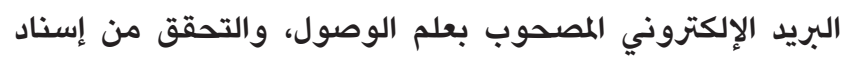

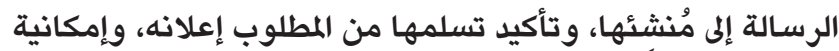
حفظ وأرشفة الإعلانات الإلكترونية.

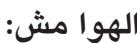


استلامه الصورة أو خاتمه أو بصمة إبهامه على الأصل بالاستلام.

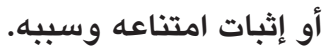

(1) الفقرة الرابعة من المادة الخامسة من قانون الإجراءات

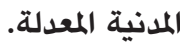

(Ir) وتشترط بعض التشريعات موافقة الأطراف صراحة على

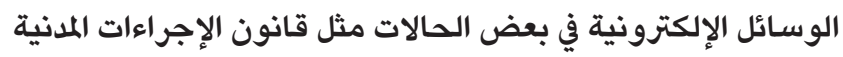

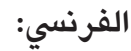

Code de procédure civile (Article 748-2): Le destinataire des envois, remises et notifications mentionnés à I sarticle 748-1 doit consentir expressément à I sutilisation de la voie électronique. (inséré par Décret no 2005-1678 du 28 décembre 2005 art. 73 Journal Officiel du 29 décembre 2005 en vigueur le 1er janvier 2009 sous réserve art. 88).

(r) وقد قيدت أغلب التشريعات الإعلان القضائي بالبريد الإلكتروني، وكثير منها يتطلب التصريح من المحكمة قبل الإعلان.

$$
\text { ( ع ا ) انظر: قانون الإجراءات المدنية الفرنسي: }
$$

Code de procédure civile (Article 748-6): Les procédés techniques utilisés doivent garantir, dans des conditions fixées par arrêté du garde des sceaux, ministre de la justice, la fiabilité de Isidentification des parties à la communication électronique, lsintégrité des documents adressés, la sécurité et la confidentialité des échanges, la conservation des transmissions opérées et permettre drétablir de manière certaine la date dienvoi et celle de la réception par le destinataire. (inséré par Décret no 2005-1678 du 28 décembre 2005 art. 73 Journal Officiel du 29 décembre 2005 en vigueur le 1er janvier 2009 sous réserve art. 88).

(10) - (10)

The Principles of European Contract Law (PECL) which are based on the concept of a uniform European contract law system, and were created by the selfstyled Commission on European Contract Law set up by "Ole Lando Commission".

PLCL Art 1:301(6) stipulates that '“written' statements include communications made by telegram, telex, telefax and electronic mail and other means of communication capable of providing a readable

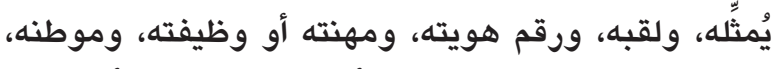

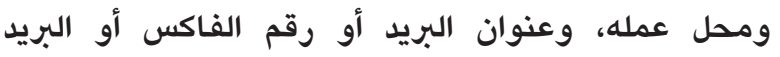

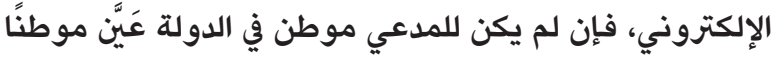
مختارًا له. - الهي،

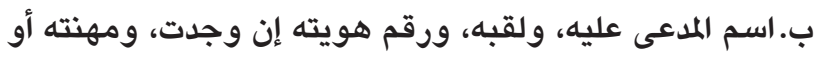

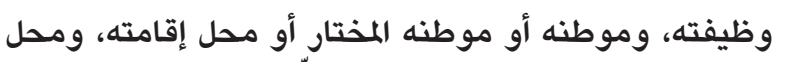

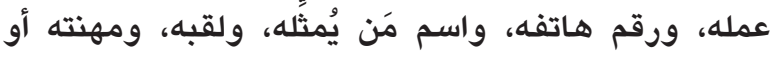

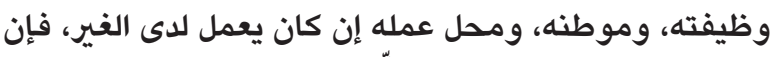

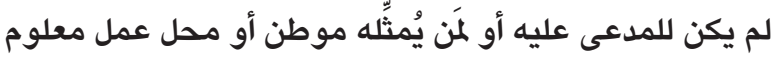

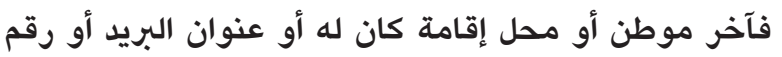
الفاكس أو البريد الإلكتروني. ج. موضوع الدعوى والطلبات وأسانيدها. د. تاريخ إيداع صحيفة الدعوى بمكتب إدارة الدوات وأدوان. هـ المحكمة المرفوعة أمامها الدعوى. و. توقيع المدعي أو مَن يمثله).

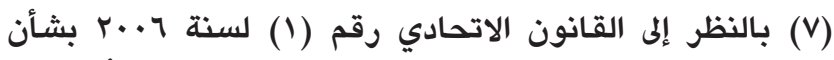

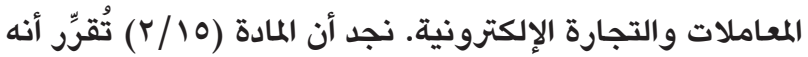

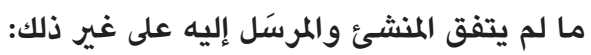

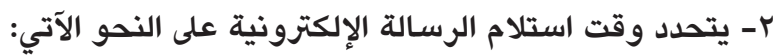

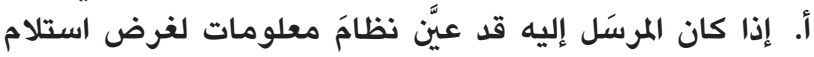

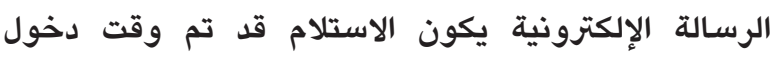

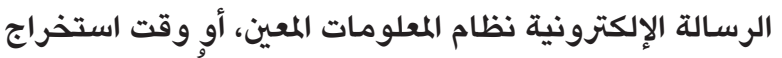

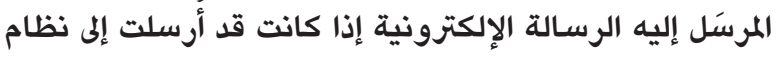

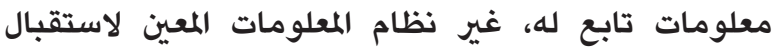

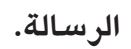
ب.إذا لم يعيّن المرسَل إليه نظامَ معلومات، يقع الاستلام عندما

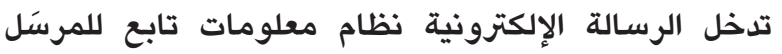

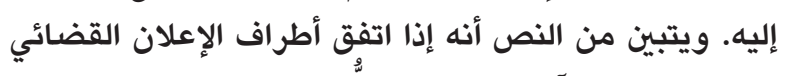

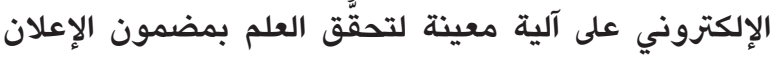
فإن هذه الآلية هي الواجب الاعتئ معينة لاعتماد عليها في تحديد وقت الإعلان

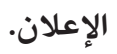

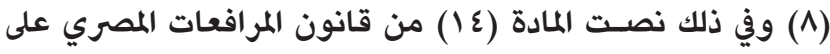

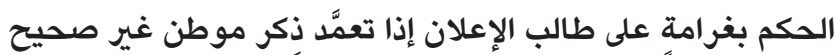
للمُعلَن إليه بقصد عدم وصول الإعلان إليه.

(9) وعلى خلاف ذلك لم تُشر إليه المادة (9) من قانون المرافعات

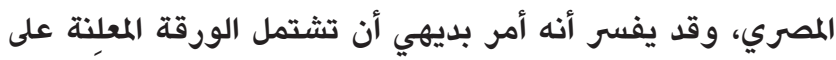

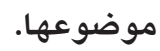

(·) وتثور الإشكالية في حالة الإعلان التقليدي إذا كان مستلم

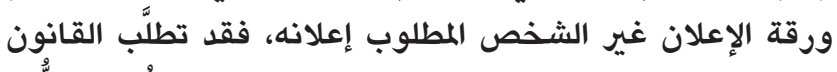

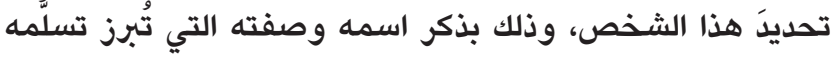

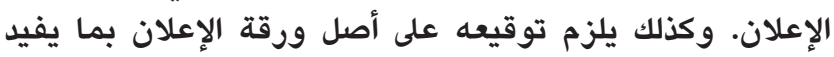


بحسب الأحوال- أنه ليس للمطلوب إعلانه موطن، أو محل إقامة،

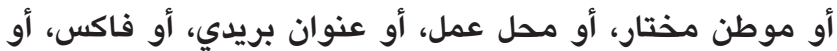
بريد إلكتروني، أو لم يتفق الطرفان على وسيلة للإعلان؛ فيتم إعلانه على لوحة الإعلانات بالمحكمة، وباللصق بـولى بشكل واضح على على باب آخر مكان كان يقيم فيه إن وُجد، أو بالنشر في صحيفة يومية بالية

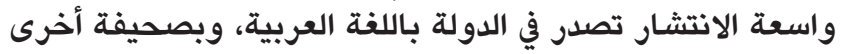
تصدر بلغة أجنبية إن اقتضى الأمر إذا كان المطلوب إعلانه أجنبيًّا،

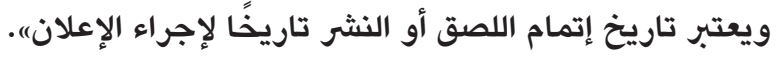

(Yr) على خلاف المُشرِّع الكويتي الذي نص بالمادة (0) في فقرتها الرابعة من قانون المرافعات المدنية والتجارية الصادر بالمرسوم

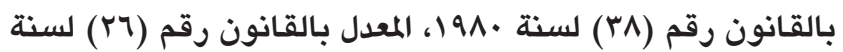

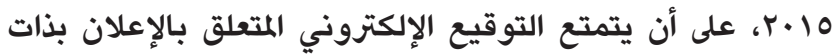

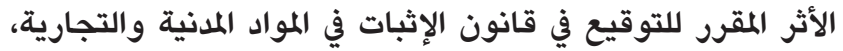
بشرط استيفائه للشروط والمواصفات المطلوبة في التوقيع الإلكتروني، والتي توفر الثقة في الوسائل التقنية المستخدمة، وسلامة المعلومات الموثقة، وإمكانية حفظ الماتية المستند الإلكتروني الموقع، وغيرها من الضوابط التقنية والفنية التي يصدر بها القرار الوزاري المشار إليه. - مئ.

(ع (ץ) راجع تعريف الكتابة الإلكترونية الوارد بنص المادة ( () من

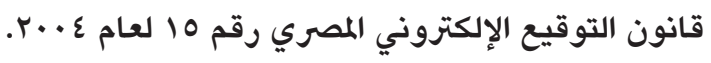

(Yo) بينما أشارت الفقرات الأولى من النص إلى أنه: „ا- يعتبر

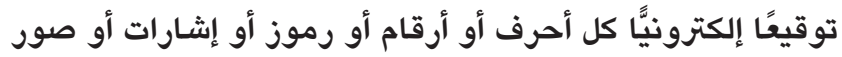

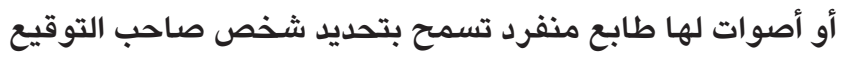
وتمييزه عن غيره على النحو الوارد في قانون المعاملات والتجارة

الإلكترونية.

r- يعتبر محررًا إلكترونيًا كل انتقال أو إرسال أو استقبال

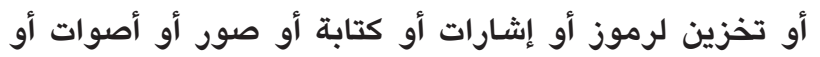

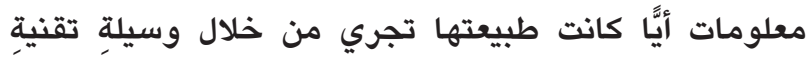
معلومات. r- للتوقيع الإلكتروني ذات الحجية المقررة للتوقيعات المشار إليها في هذا القانون، إذا روعي فيه الأحكام المقررة في قانون المعاملات و التجارة الإلكترونية)،

(YT) وقد ورد تعريف المستند الإلكتروني بصفة عامة بصدر

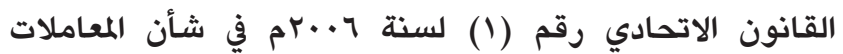
والتجارة الإلكترونية، حيث نصت المادة الأولى منه على أن "السجل

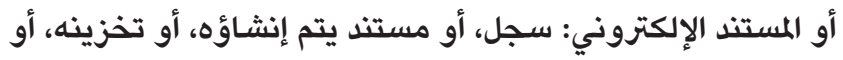

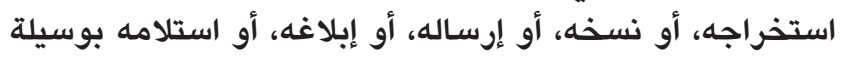

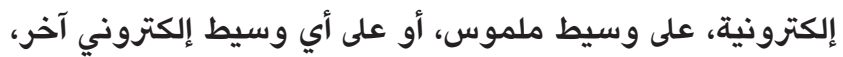

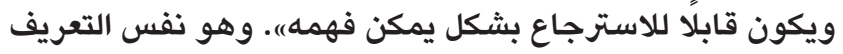

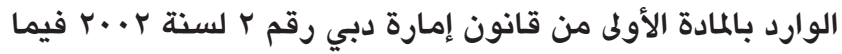
يتعلق بالمعاملات والتجارة الإلكترونية. record of the statement on both sides".

Art. 6 of "UNCITRAL Model Law on Electronic Commerce»،stipulates phrase ("accessible as to be usable for subsequent reference")

(IV)

The Uniform Electronic Transactions Act (UETA), it is one of the several United States Uniform Acts proposed by the National Conference of Commissioners on Uniform State Laws (NCCUSL). Forty-seven states, the District of Columbia, Puerto Rico, and the U.S. Virgin Islands have adopted the UETA. Its purpose is to harmonize state laws concerning retention of paper records (especially checks) and the validity of electronic signatures. Art. 6 (13)2 stipulates phrase ("retrievable in perceivable form").

(1^) فلا يكون لمكان استلام الإعلان الإلكتروني فائدةٌ تُذكَر إلا إذا

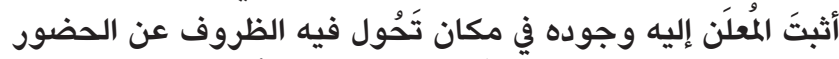

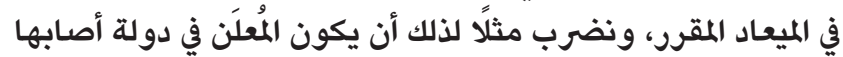

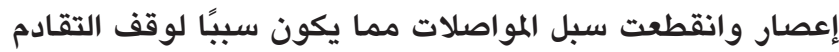
أو مُدَد السقوط مثلاً حتى ولو تم الإعلان.

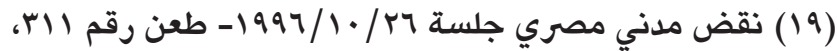

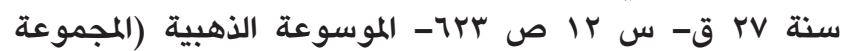

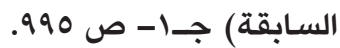

(Y.) وكان النص المُلغَى يقرر أنه: (ر - تُضاف إلى المواعيد المبيَّنة في هذا القانون ميعاد مسافة عشرة أيام لمن يكون موطنه خارج دائرة المحكمة وتسعون يومًا لمن يكون موطنه خارج دولة الإمارات

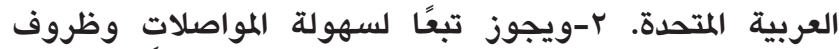

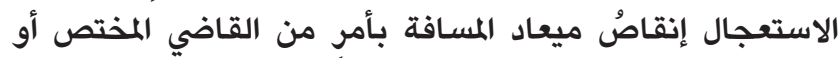

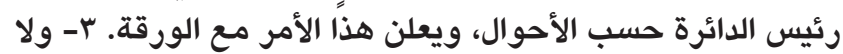

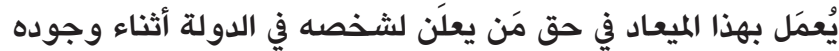

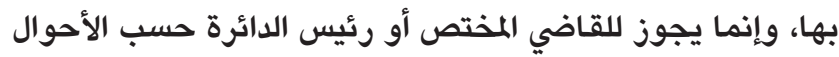

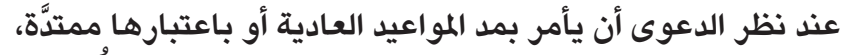

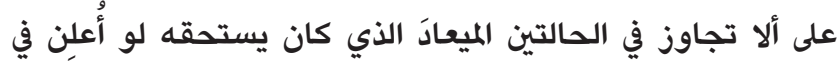

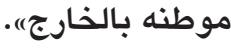

(Y) ما لم يثبت وجود قوة قاهرة أو سبب أجنبي يمنعه من الحضور كما أسلفنا.

(YT) وقد نص البند (ع) من المادة (^) من هذا القانون على أنه: „إذا

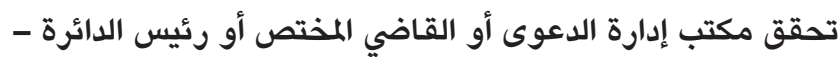


إلكترونيًا أو غير ذلك)، وتُعرَّف المعاملات الإلكترونية المُؤتَمَتَة،

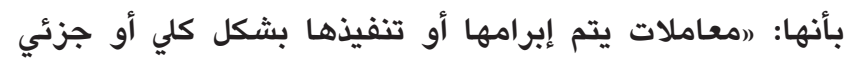

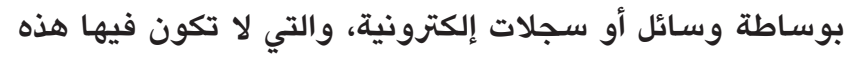

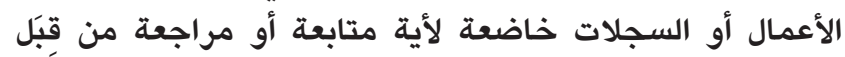

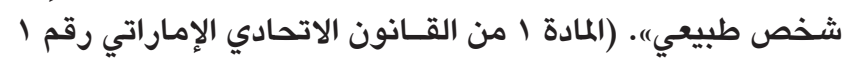

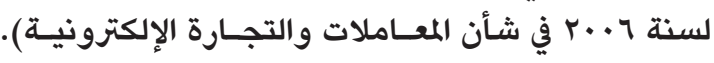

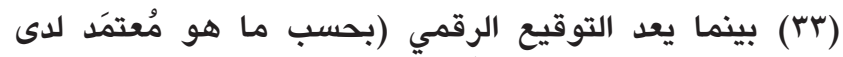

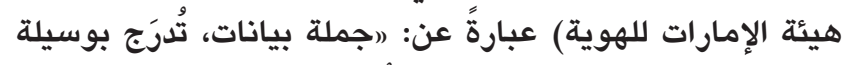

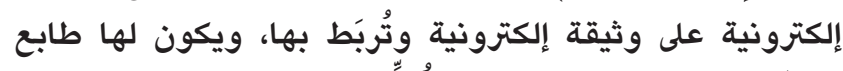

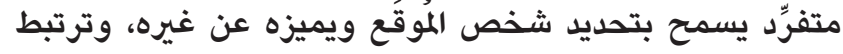

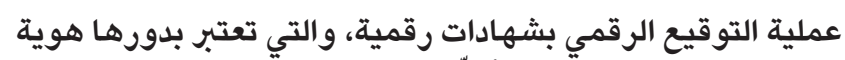

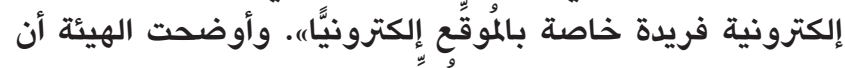

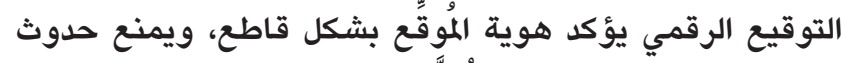

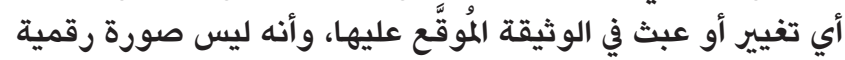

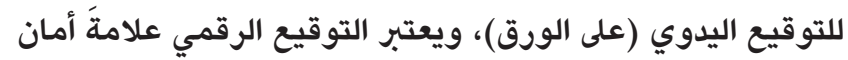

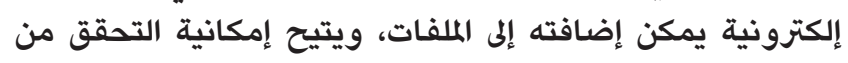

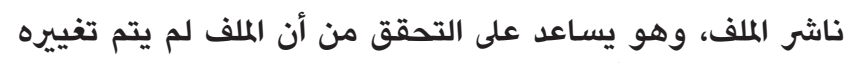

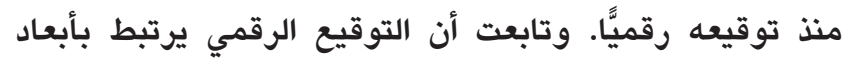

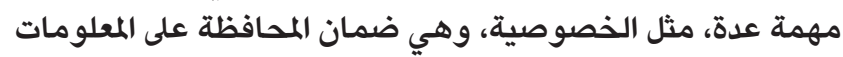

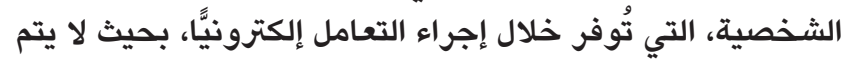

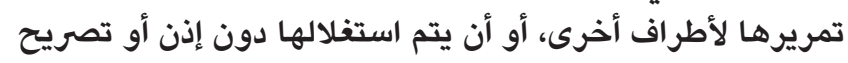

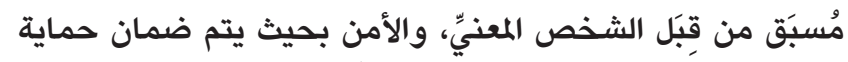

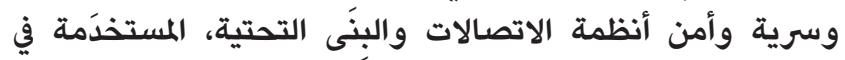

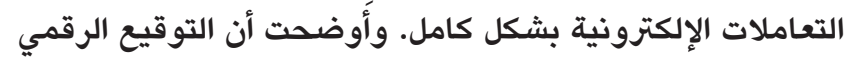

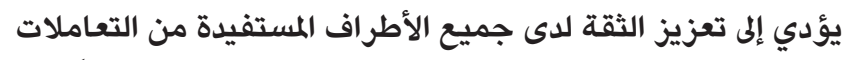

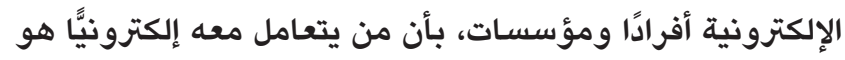

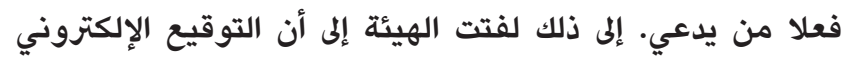

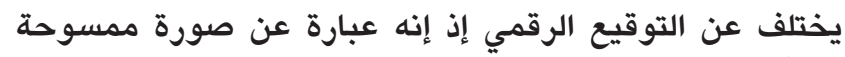

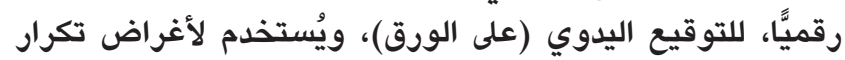
التوقيع على المطبوعات، وتذييل الميلوي المراسلات الإلكترونية.

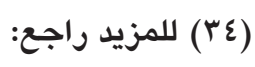

Journal officiel des Communautés européennes ,(J.O.C.E L.). (13،19 janvier 2000) P. 12 ets.

(ro) حيث عرف "مُقدِّم خدمات تصديقه بأنه: شخص يُصدِر

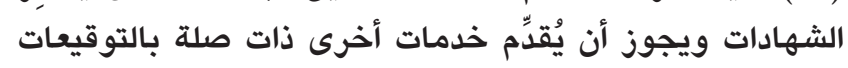

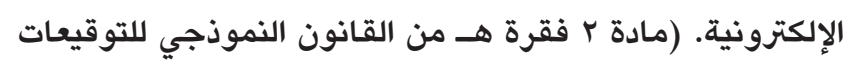
الإلكترونية الصادر عام ( +. r م).

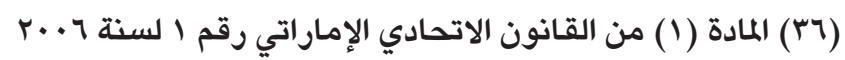
في شأن المعاملات والتجارة الإلكترونية.

(YV) الحيثية رقم (9)، والحيثية رقم (^l^) من التوجيه الأوروبي.

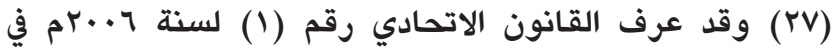

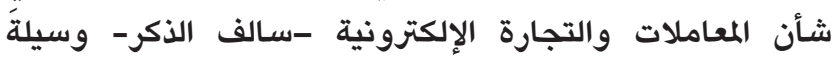

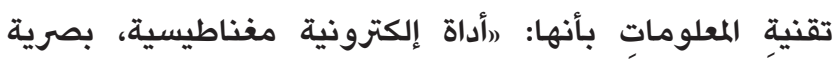

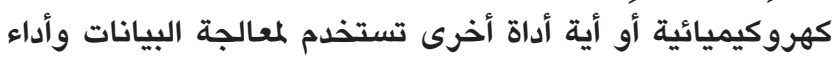

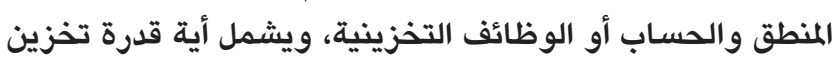
بيانات أو اتصالات تتعلق أو تعمل بالاقتران مع مثل هذه الأداة).

(rN) هذا بخلاف الشروط والأحكام المقررة في قانون المعاملات

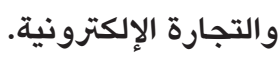

(r9) فلا يجوز على سبيل المثال قيام أحد الطرفين بتوجيه اليمين الحاسمة للآخر أو استخدام أي وسيلة أخرى من وسائل الإثبات الأخرى لإثبات عكس ما ورد في الإعلان القضائي.

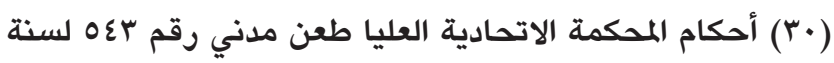

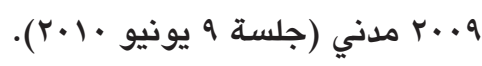

(T) ونتوه إلى أن القانون لا يسري على أي مستند يتطلب القانون

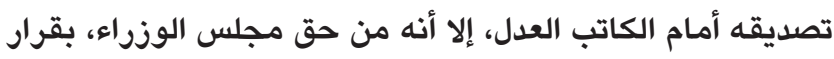
يصدره أن يضيف أية معاملات أو مسائل أخرى أو أو أن يحذف من الونف منها

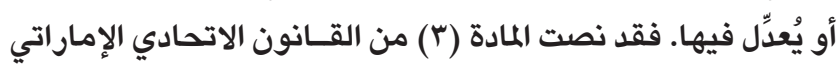

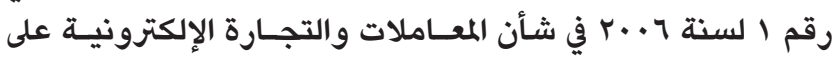

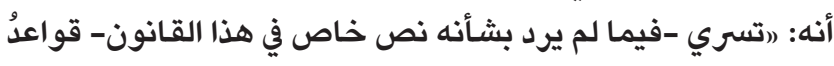

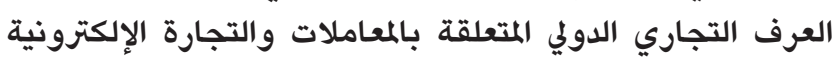

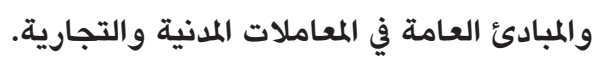

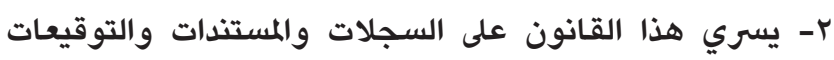

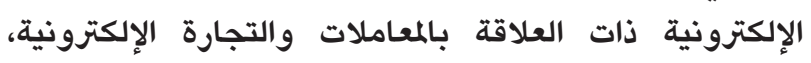

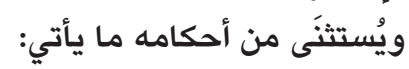
أ. المعاملات والمسائل المتعلقة بالئي: بأحوال الشخصية كالزواج والطلاق والوصايا.

ب. سندات ملكية الأموال غير المنقولة.

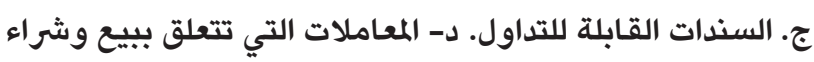

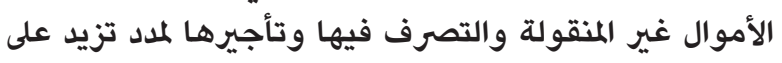

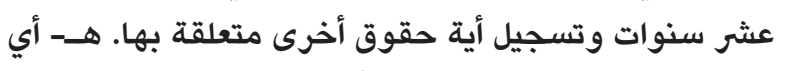
مستند يتطلب القانون تصديقه أمام الكاتب العدل.

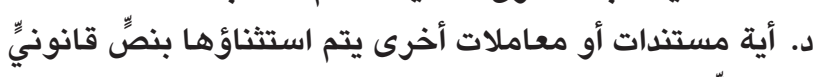

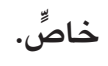

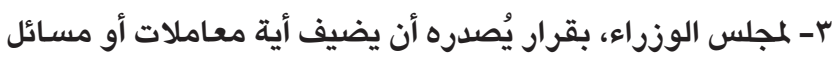

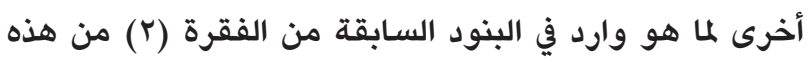
المادة، أو أن يَحذف منها أو يُعدّل فيهاها،

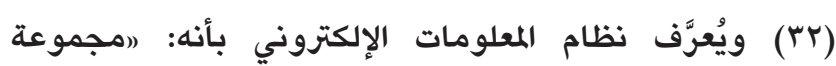

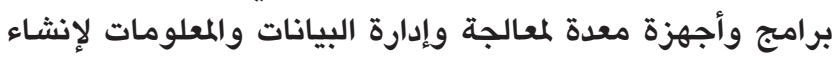

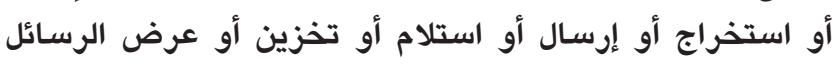


الصاوي، محمد، ب. ..r. الوجيز في شرح قانون المرافعات المدنية، دار النهضة العربية، القاهرة. عبد الستار، قيس، ع ا.r. أحكام وقواعد الإثبات وفقًا لقانون

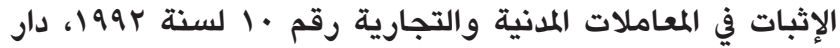
الكتاب الجامعي، الشارقة.

عبيدات، يوسف، r ا • r. أحكام الإثبات في المواد المدنية والتجارية

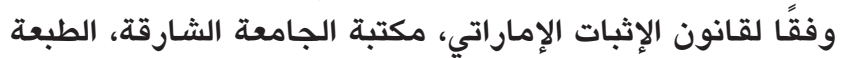
الأولى.

العبيدي، علي هادي، با • r. قواعد إسناد الرسالة الإلكترونية إلى

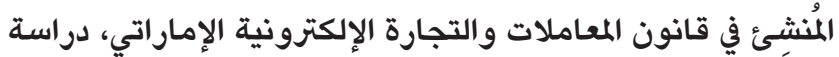
مقارنة، مجلة الشريعة والقانون بجامعة الإمارات، العدد عه.

قنديل، مصطفى، 10 •r. الوجيز في القضاء والتقاضي، الآفاق المشرقة، الشارقة.

مأمون، إيمان، 7 · • r. الجوانب القانونية لعقد التجارة الإلكترونية، رسالة دكتوراه، كلية الحقوق- جامعة المنصورة.

موسى، مصطفى أبو مندور، 7 أr. مفهوم المحرر الإلكتروني المُعدّ للإثبات (دراسة مقارنة)، مجلة البحوث القانونية والاقتصادية بكلية الحقوق- جامعة المنصورة، العدد •7، V79 وما بعدها.

نجاشي، عبد الحميد، rا ـr. أحكام الإثبات، طץ، الآفاق المشرقة ناشرون، الشارقة.

النيادي، الأنصاري حسن، 9. . ب. القاضي والوسائل الإلكترونية الحديثة، دار الجامعة، الإسكندرية.

يس، عبد الرازق، ^ • · . ش شرح القواعد الموضوعية لإثبات المعاملات

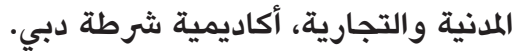

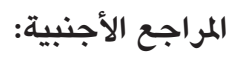

CAPRIOLI (E.), 1999, le juge et la preuve électronique, juriscom. net, revue du droit des technologies de l'information, 10 janvier 2000. texte présenté au colloque de Strasbourg, "Le commerce électronique: vers un nouveau droit.

Friedenthal (J), Kane(M), Miller(M), 5 ,2015thEdition,

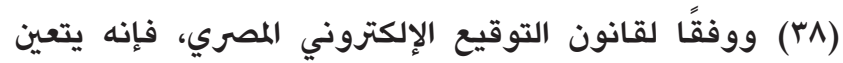
الحصول على ترخيص بذلك من هيئة تنمية صناعة تكنولوجيا

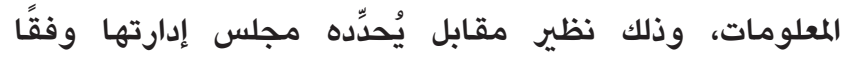
للإجراءات والقواعد والضمانات التي تُقرِّرها اللائحة التنفيذية ودئ

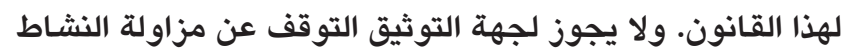

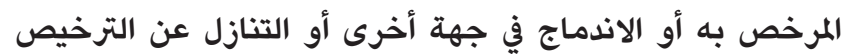

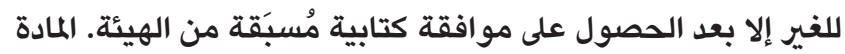
(19) من قانون التوقيع الإلكتروني المصري. (ץ) (المادة (ץ) من الاتفاقية. ( • (ع) المادة (Y) من الاتفاقية. المراجع

إبراهيم، محمد محمود، 191 أـ أصول صحف الدعاوى، دار الفكر

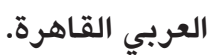

أبو هيبة، نجوى؛ الصاوي، أحمد محمد، 10 •r. شرح أحكام قانون الإثبات، دار النهضة العربية، القـاهرة.

أبو هيبة، نجوى، ب. +. . حجية التوقيع الإلكتروني، بحث منشور

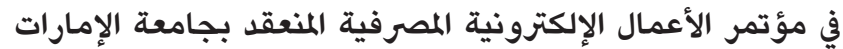

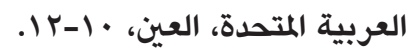

جميعي، حسن عبد الباسط، ... إثبات التصرفات الإلكترونية التي يتم إبرامها عن طريق الإنترنت، دار النهضة العربية، القاهرة.

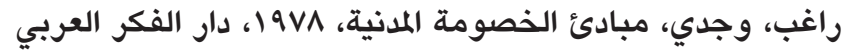
للطباعة و النشر، القاهرة.

زهرة، محمد المرسي، ب991. الحاسب الإلكتروني دراسة حول حجية مخرجات الحاسب الإلكتروني في الإثبات في المسائل المدنية والتجارية، مكتبة وهبة، القاهرة.

السرحان، بكر عبد الفتاح، 10 ب. إ. تعديلات الإعلان القضائي

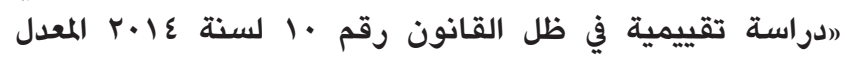
لقانون الإجراءات المدنية الاتحاديه،، مجلة الدراسات القضائية، العدد الخامس عشر، السنة الثامنة.

صاوي، أحمد السيد، ع991. الوسيط في شرح قانون المرافعات المدنية والتجارية، دار النهضة العربية، القاهرية العرة. 
Civil Procedure, West Academic.

Hondius (E.H.), 2004, Towards a European Civil Code, Kluwer Law International.

MOREL (R), 1949, Traite élémentaire de procédure civile, 2e éd. Sirey, n. 386. 